\title{
"ESRB WARNING: USE OF VIRTUAL WORLDS BY CHILDREN MAY RESULT IN ADDICTION AND BLURRING OF BORDERS" - THE ADVISABLE REgulations IN Light OF FoRESEEABLE DAMAGES
}

\author{
By Nachshon Goltz \\ Volume XI - Fall 2010 \\ Copyright (C) Pittsburgh Journal of Technology Law and Policy
}

\begin{abstract}
This article analyzes the possible models for regulating the use of Internet-based virtual worlds by minors. While virtual worlds introduce a unique experience to their users, there is a strong indication that such use, if left unregulated, may cause harm, especially to minors. This article explains that the dangers associated with virtual worlds are different from those created by other types of media. The various phenomena which may be caused due to the use of virtual worlds and the damages likely to be caused by such phenomena, rest on two assumptions: that minors are especially prone to suffer from such dangers, since the exposure of minors to the experiences offered by virtual worlds is not mitigated by factors such as a more developed sense of reality and responsibility, and, that in the use of virtual worlds there is a greater potential to induce such harms when compared to the use of video games or other Internet applications. The methodology underlying this article is based on a comparativecritical review of the existing literature in the fields relevant to this interdisciplinary realm: technology, psychology, philosophy and law. This article concludes that non-legal regulation is insufficient and puts forth several suggestions for legal regulation. The proposed regulation is based on four principles: Awareness - forcing virtual worlds companies to issue a warning of the possible damages similar to the warnings printed on cigarettes packs; Prevention operating technological measures to identify minor users and tracking their use length; Help establishing help centers and posting distress buttons in the virtual world; and Liability imposing tort liability on virtual worlds companies that fail to implement the proposed changes.
\end{abstract}




\section{"ESRB WARNING: USE OF VIRTUAL WORLDS BY CHILDREN MAY RESULT IN ADDICTION AND BLURRING OF BORDERS" - THE ADVISABLE REgULATIONS IN LIGHT OF FORESEEABLE DAMAGES}

By Nachshon Goltz

Volume XI - Fall 2010

Copyright (C) Pittsburgh Journal of Technology Law and Policy

\section{TABLE OF CONTENTS}

\begin{tabular}{|c|c|}
\hline I. INTRODUCTION. & 2 \\
\hline II. VIRTUAL WORLDS $\ldots \ldots \ldots \ldots \ldots \ldots \ldots \ldots \ldots \ldots \ldots \ldots \ldots \ldots \ldots \ldots$ & 4 \\
\hline 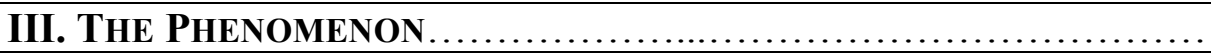 & 7 \\
\hline 1. INTERNET ADDICTION..................................... & 7 \\
\hline 2. BLURRING OF BORDERS.......................................... & 13 \\
\hline 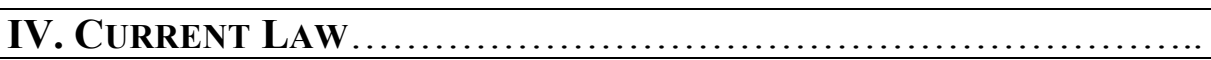 & 18 \\
\hline 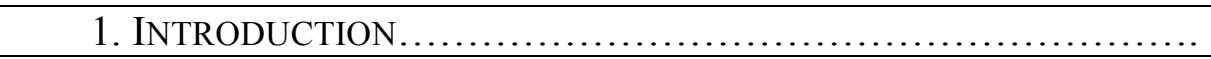 & 18 \\
\hline 2. THE LAW IN CALIFORNIA. & 23 \\
\hline A. Cause of Action in Tort.................................. & 24 \\
\hline (1) Negligent Infliction of Emotional Distress............ & 25 \\
\hline (2) Manufacturer's Liability $\ldots \ldots \ldots \ldots \ldots \ldots \ldots \ldots \ldots \ldots$ & 28 \\
\hline B. The Liability Waiver in the Terms of Service.............. & 31 \\
\hline (1) Contracts Aspect.............................. & 31 \\
\hline (2) Consumer Protection Aspect...................... & 33 \\
\hline C. ISP and Constitutional Immunity........................ & 34 \\
\hline (1) Internet Service Providers Immunity............... & 34 \\
\hline (2) Constitutional Immunity........................ & 38 \\
\hline D. Parents Liability $\ldots \ldots \ldots \ldots \ldots \ldots \ldots \ldots \ldots \ldots \ldots \ldots \ldots \ldots$ & 40 \\
\hline 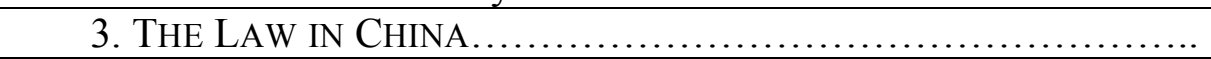 & 43 \\
\hline 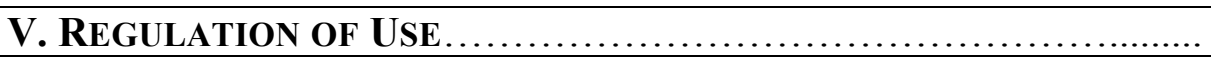 & 46 \\
\hline$\ldots \ldots \ldots \ldots \ldots \ldots \ldots \ldots \ldots \ldots \ldots$ & 46 \\
\hline A. Objection to Legal Regulation........................ & 46 \\
\hline B. Support for Legal Regulation............................. & 47 \\
\hline 2. REGULATION MODELS........................................ & 49 \\
\hline 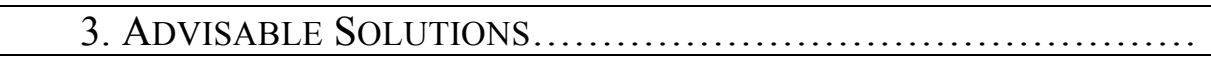 & 52 \\
\hline A. The Property Aspect................................. & 52 \\
\hline (1) A Two-Tier Regulation - Internal \& External......... & 52 \\
\hline 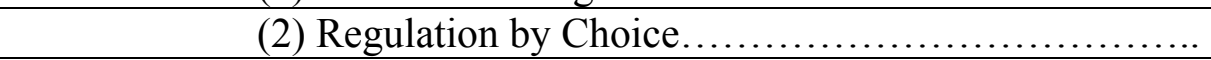 & 53 \\
\hline (3) Self-Regulation................................... & 54 \\
\hline (4) "No Sale" Servers................................. & 56 \\
\hline (5) Virtual Worlds Council............................... & 57 \\
\hline 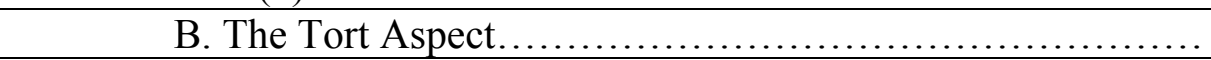 & 57 \\
\hline (1) Awareness........................................... & 58 \\
\hline 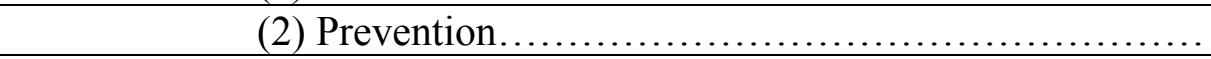 & 58 \\
\hline 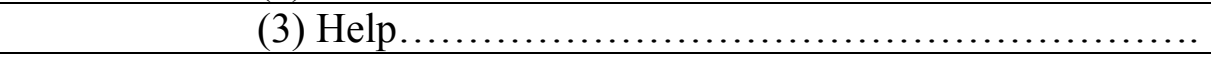 & 59 \\
\hline 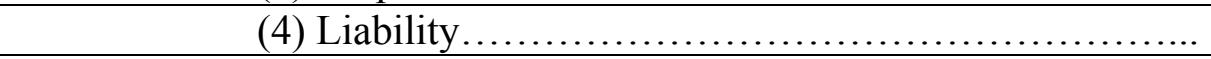 & 59 \\
\hline 4. SUMMARY $\ldots \ldots \ldots \ldots \ldots \ldots \ldots \ldots \ldots \ldots \ldots \ldots \ldots \ldots \ldots \ldots \ldots \ldots \ldots$ & 59 \\
\hline 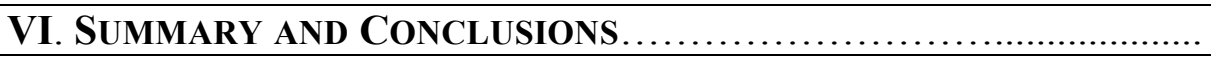 & 60 \\
\hline
\end{tabular}




\title{
"ESRB ${ }^{1}$ WARNING: USE OF VIRTUAL WORLDS BY CHILDREN MAY RESULT IN ADDICTION AND BLURRING OF BORDERS" - THE ADVISABLE REgUlations IN LIGHT OF FORESEEABLE DAMAGES
}

\author{
By Nachshon Goltz ${ }^{2}$ \\ Volume XI - Fall 2010 \\ Copyright $(\odot$ Pittsburgh Journal of Technology Law and Policy
}

"When a thing is considered in terms of its beginning, a thing is always poorly judged." ${ }^{3}$

"Every day the urge grows stronger to get hold of an object at very close range by way of its likeness, its reproduction." ${ }^{4}$

\section{INTRODUCTION}

It is hard to decide which is more horrible and alarming: the death of 3-month-old Sarang ("love" in Korean) as a result of her parents neglecting her in order to raise a virtual baby in a virtual world, ${ }^{5}$ or the 22-year-old arrested last February for clubbing his 53 year-old

\footnotetext{
${ }^{1}$ Entertainment Software Rating Board, http://www.esrb.org/index-js.jsp (last visited October 27, 2010) (A "non-profit self-regulatory body that independently assigns rating, enforces advertising guidelines, and helps ensure responsible online privacy practices for the interactive software industry."); Sara M. Grimes, Kids" Ad Play: Regulating Children's Advergames in the Converging Media Context, INT'L J. COMM. L. \& POL'Y 161 (2008).

${ }^{2} \mathrm{PhD}$ Candidate, Osgoode Hall Law School, York University. The author wishes to thank Prof. Amnon Reichman of Haifa University, for his wise advice and patient guidance, Adv. Jodi Patt for her amazing work in reviewing this article, the editors of JTLP for their comments and to my wife and children for their loving support.

${ }^{3}$ Gilles Deleuze \& Felix Guatarri, Anti-Oedipus: Capitalism and Schizophrenia 91 (Robert Hurley et al. trans. 1972).

${ }^{4}$ WALTER BENJAMIN, The Work of Art in the Mechanical Age of Reproduction, in ILLUMINATIONS 217 (H. Arendt ed., H. Zohn, trans. 1973), available at http://www.marxists.org/reference/subject/philosophy/works/ge/benjamin.htm.

${ }^{5}$ Choe Sang-Hun, South Korea Expends Aid for Internet Addiction, N.Y. TIMES, May 28, 2010, at A4, available at http://www.nytimes.com/2010/05/29/world/asia/29game.html.
} 
mother to death after she criticized his online gaming habit. ${ }^{6}$ Either way, it seems we are facing a serious worldwide problem. ${ }^{7}$

Virtual worlds are the next generation of Internet use and social networking. ${ }^{8}$ They introduce a unique experience to their users. Along with enriching aspects, positive experiences, and many varied uses, virtual worlds also conceal several phenomena, each of which has the potential of causing damage to the user, especially the minor user. These phenomena include Internet addiction and the blurring of borders between the virtual and real world, which can interfere with daily life, and may impair reality perception (hereinafter: "The Phenomenon").

Review of the Phenomenon which might be caused by the use of virtual worlds, and the damages likely to be caused by it, will be based on two assumptions: first, that minors are especially exposed to the Phenomenon and the damages which might be caused by it, and second, that in the use of virtual worlds there is a greater potential for these damages to occur than in the use of video games or other Internet applications.

This article will first review virtual worlds as an emerging technology. Second, this article will examine the Phenomenon of Internet addiction, as it relates to virtual worlds and especially the use of virtual worlds by minors. Third, this article will discuss the Phenomenon of the blurring of borders between real and virtual worlds, drawing conclusions from the comprehensive research conducted on video games use. Fourth, this article will review the current legal situation regarding the regulation of virtual worlds. Finally, this article will examine the current scholarly approach to the regulation of virtual worlds and will introduce proposed regulatory solutions.

\footnotetext{
${ }^{6}$ S. Korean Jailed for Killing Mother Over Gaming Addiction, AFP, July 2, 2010, available at http://www.google.com/hostednews/afp/article/ALeqM5iSGEydod6Z_YdAeX5n3bu7BKO47Q (last visited October 27, 2010).

${ }^{7}$ See Tara Parker-Pope, An Ugly Toll of Technology: Impatience and Forgetfulness, N.Y. TIMES, June 6, 2010, at A13, available at http://www.nytimes.com/2010/06/07/technology/07brainside.html.

${ }^{8}$ See Matt Richtel \& Brad Stone, Doll Web Sites Drive Girls to Stay Home and Play, N.Y. TimeS, June 6, 2007, available at http://www.nytimes.com/2007/06/06/technology/06doll.html.
} 


\section{VIRTUAL WORLDS}

A virtual world is a fictitious environment created by computer software enabling users to interact with other users and with the software itself using two- or three-dimensional figures called Avatars, which are created by the software. ${ }^{9}$ Communication between the users is performed through text, graphics, and Avatar movements, gestures and sounds. ${ }^{10}$ The user logs onto the Internet to a server hosting the software creating the virtual world. This software introduces the user to perceptive stimulus, and the user can manipulate objects in the presented environment, thereby experiencing virtual presence to a certain degree. These virtual worlds can look similar to the real world or to a fantasy world - a world in which the rules of nature are different than the rules of the real world or the view and the characters in it are not known in reality. ${ }^{11}$

It has been argued that the most prominent difference between virtual worlds and video games are that virtual worlds are both persistent and dynamic. ${ }^{12}$ Even when you are not in the virtual world, the virtual environment continues to exist and change over time. ${ }^{13}$ It has

\footnotetext{
${ }^{9}$ The root of the word "Avatar" comes from a term in Hindu philosophy meaning the incarnation of the divine entity on Earth. In the virtual world, the Avatar has transformed into the visual representation of the user. NEAL STEPHENSON, SNOW CRASH (1992).

${ }^{10}$ See Martin Wadley \& Peter Benda, Speaking in Character: Using Voice-Over-IP to Communicate Within MMORPGs (IE '07 Proceedings of the 4th Australasian conference on Interactive entertainment, Working Paper, 2007), available at http://delivery.acm.org/10.1145/1370000/1367980/a24wadley.pdf?key $1=1367980 \&$ key $2=4213828821 \&$ coll $=$ GUIDE $\& d l=$ GUIDE $\&$ CFID $=110737066 \&$ CFTOKEN $=6$ 3827562.

${ }^{11}$ See Dan Hunter, Cyberspace as Place and the Tragedy of the Digital Anticommons, 91 CAL. L. REV. 439,456 (2003) (describing how society tends to visualize the Virtual World as a "place"- an example being the idea that people "explore" imaginary worlds on the Internet through online gaming communities such as, EverQuest, Ultima Online, Star Wars Galaxies, and Asheron's Call).

${ }^{12}$ See Jacob Rogers, A Passive Approach to Regulation of Virtual Worlds, 76 GEO. WASH. L. REV. 405 (2008).

${ }^{13}$ See, e.g., Gregory F. Lastowka \& Dan Hunter, The Laws of the Virtual Worlds, 92 CAL. L. REV. 1, 6 (2004); Edward Castronovo, Synthetic Worlds: The Business and Culture of Online Games 65-67 (2005) (Describing persistence as "the most innovative feature" of virtual worlds. They must also be interactive and governed by physical rules (although often different rules than those governing the real world)).
} 
also been suggested that we can characterize virtual worlds on the base of 3D3C model - a 3dimensional world in which exists Community, Commerce, and Creation. ${ }^{14}$

Today there are two main types of online virtual worlds: ${ }^{15}$ Massively Multiplayer Online Role Playing Games (MMORPG's) ${ }^{16}$ and Massively Multiplayer Online Games (MMOG's). ${ }^{17}$ It is estimated that 27 million people worldwide are visiting online virtual worlds every week, one third of them from South Korea, the country with the largest broadband penetration in the world. ${ }^{18}$ Marketing research has revealed that the expansion of virtual worlds is a global phenomenon and that $80 \%$ of the people using the Internet (1.6 billion worldwide) will work or play in virtual worlds by $2011 .{ }^{19}$ In the first quarter of 2008 , 184 million dollars were invested in developing and building virtual worlds, with more than one-third of this sum invested in virtual worlds for children. ${ }^{20}$

Virtual worlds are very popular among children. For example, in the summer of 2007, the children's virtual world ClubPenguin had 700,000 paying subscribers and claimed

\footnotetext{
${ }^{14}$ See Yesha Y. Sivan, The 3D3C Metaverse: A New Medium is Born in New MEdiA AND InNOvATIVE TECHNOLOGIES 132 (Tal Samuel-Azran \& Dan Caspi eds. 2008), available at http://sites.google.com/site/yeshasivan/3D3CMetaversethatDefineRealVirtualWo.pdf?attredirects $=0$.

${ }^{15}$ For the development of virtual worlds see DANIEL MACKAY, THE FANTASY ROLE-Playing GAME: A NEW Performing Art 13 (2001); Steven L. Kent, The Ultimate History Of Video Games: From Pong to Pokemon - The Story Behind that Touched Our Lives AND Changed THE World 186-88 (2001); Lauren P. Burka, A Hypertext History of Multi-User Dimensions (1993), CSun.edu, http://www.csun.edu/ hceng028/mhist.txt (last visited October 27, 2010); OLIVER GRAU, VIRTUAL ART: FrOM ILLUSION TO IMMERSION 5 (Gloria Custance trans., Reimer 2003) (2001); Edward Castronova, On Virtual Economies (CESIfo Working Paper No. 752, 2002), available at http://papers.ssrn.com/abstract=338500; DAVID KUSHNER, MATER OF DOOM: HOW TWO GuYs CREATED AN EMPIRE AND TRANSFORMEd Pop Culture 68 (2003); Gregory F. Lastowka \& Dan Hunter, The Laws of the Virtual Worlds, 92 CAL. L. REV. 1, 5 (2004).

${ }^{16}$ A virtual world in which the developers define the direction and the goals of the game. These worlds can be played alone, but are usually played in groups connected as a "guild" in order to complete a task, a goal or an adventure together. The aim of the player is to move his Avatar up through the levels of the game ("leveling"). The higher the Avatar ascends, the more "power" and abilities he possesses.

${ }^{17}$ A virtual world that enables the users to define the character of the game. The more advanced MMOGs enable the player to buy land, build objects, and build houses.

${ }^{18}$ See Tim Guest, Just a Game?, NEw ScIENTIST, May 20, 2006, at 38.

${ }^{19}$ Jessica Bennett \& Malcolm Beith, Alternate Universe, NEWSWEEK, Jul. 30, 2007, available at http://www.newsweek.com/id/32824.

${ }^{20}$ Ken Schachter, Investors Pour \$184M into Virtual Worlds, redherring.com, http://www.redherring.com/home/24182 (last visited October 27, 2010).
} 
more than 12 million active users, mainly in the United States and Canada. ${ }^{21}$ Another virtual world for children, Barbiegirls by Mattel, attracted 3 million users within 60 days of its launch. By April 2008, Barbiegirls by Mattel had more than 10 million users. ${ }^{22}$ This record growth is predicted to continue.

Today there are more than 150 virtual worlds, active or in development, marketing to youth, ages 18 and below. Of those, 88 virtual worlds are aimed at users between the ages of 8 and 12 (16 more than in April 2008) and 72 are aimed at users 7 years old and younger (20 more than in April 2008). ${ }^{23}$ It has been estimated that by 2011, approximately 20 million American youth between the ages of 3 and 17 (53\% of this age group) will visit virtual worlds at least once a month. ${ }^{24}$ In comparison, in 2007 approximately 8.2 million American youth between the ages of 3 and 17 (24\% of this age group) visited virtual worlds at least once a month and $9 \%$ of this age group visited virtual worlds at least once a week. An additional study reported that $97 \%$ of Americans between the ages of 12 and 17 play computer games, of which 10\% report using MMOG's and 21\% report using MMORPG's. ${ }^{25}$ The research company eMarketer estimates that at least 8.2 million children are members of at least one virtual world. ${ }^{26}$

In reference to economics, the research company Piper Jaffray predicts that sums paid by Americans in virtual worlds in 2009 will reach 621 million dollars, an increase of 134\%

\footnotetext{
${ }^{21}$ Staci D. Kramer, Disney Acquires Club Penguin; \$350 Million Cash, Possible \$350 Million Earnout, Paidcontent.org, Aug. 1, 2007, http://www.paidcontent.org/entry/419-disney-acquires-club-penguin-in-dealvalues-at-700-million-to-be-brande (last visited October 27, 2010).

${ }^{22}$ Stuart Keith, Spongebob is the Real Threat to Our Children Online, The GuARDiAn (UK), Apr. 10, 2008, at 3, available at http://www.guardian.co.uk/technology/2008/apr/10/games.news.

${ }^{23}$ Virtual Worlds Management, Virtual Worlds Management Youth Worlds Analysis, Virtualworldmanagement.com (Aug. 22, 2008), http://www.virtualworldsmanagement.com/2008/youthworlds0808.html (last visited October 27, 2010).

${ }^{24}$ Debra Aho Williamson, Kids and Teens: Virtual Worlds Open New Universe, Emarketer.com (Sep. 2007), http://www.emarketer.com/Reports/All/Emarketer 2000437.aspx (last visited October 27, 2010).

${ }^{25}$ Amanda Lenhart et al., Teens, Video Games and Civics, Pew InTernet And American Life Project, Sep. 16, 2008, available at http://www.pewinternet.org/Reports/2008/Teens-Video-Games-and-Civics.aspx.

${ }^{26}$ Joseph I. Rosenbaum, Virtual Worlds for Children: an Introduction to the Issues, 10 ECOMMERCE L. \& POL'Y 10,13 (2008).
} 
from 2008. This amount is expected to continue to rise until 2013, when according to a "Pay to Play" report, the spending on virtual worlds in the USA will reach 2.5 billion dollars. ${ }^{27}$

While there are many disadvantages to virtual worlds, which will be described in the coming chapter, virtual worlds also have many advantages. ${ }^{28}$ The greatest advantage of virtual worlds is the freedom of speech they provide users and creators alike. Virtual worlds also serve many different purposes, such as increasing the quality of life of disabled individuals, educating, treating pain and illness, and much more. ${ }^{29}$

\section{The Phenomenon}

\section{INTERNET ADDICTION}

Internet Addiction Disorder (IAD) and Pathological Internet Use (PIU) are the two model primary diagnoses for Internet addiction in consultation and psychology. These two models are adopted from the diagnosis characteristics found in the Diagnostic and Statistical Manual of Mental Disorders (DSM-IV) $\left(4^{\text {th }}\right.$ edition) and are the basis for most of the research in the field. ${ }^{30}$

\footnotetext{
${ }^{27}$ Chris Sherman, Piper Jaffray: Virtual Goods Marketplace Shifting from Virtual Worlds, Virtualworldnews.com (Aug. 14, 2009), http://www.virtualworldsnews.com/2009/08/piper-jaffray-virtualgoods-marketplace-shifting-from-virtual-worlds.html (last visited October 27, 2010).

${ }^{28}$ Yochai Benkler, Coase's Penguin, or, Linux and the Nature of the Firm, 112 YALE. L.J. 369, 389 (2002) (discussing collaborative online gaming platforms like Ultima Online and EverQuest as examples of "valueadded" peer production and large-scale collaborative works created on the Internet); EDWARD CASTRONOVA, SYNTHETIC WORLDS: THE BUSINESS AND CULTURE OF ONLINE GAMES 65-67 (2005) (arguing that participation in virtual-world games like EverQuest and Ultima Online have "positive net effects" on the well being of players, and allow participants to experience different social roles and normative values).

${ }^{29}$ Rosenbaum, supra note 26, at 13 ("Purdue University is using technology used to make films like "The Lord of the Rings", to create characters in virtual world that help deaf children to learn mathematics. At Middlesex University, a Virtual Reality Laboratory... is studying how children become familiar with their environment, how to asses spatial impairment among children with disabilities and training children who suffer from dyslexia... An EU funded research project at Lab@Future is actively collaborating with schools in Slovenia to introduce a virtual world to students in which environmental awareness and the ability to survive in a virtual world are dependent upon the student's 'smart' use of non-toxic, environmentally friendly energy and food sources... At Nationwide Children's Hospital, burn victims are engaged in virtual reality games to distract them from the extreme pain associated with caring for their wounds- a real aid not only in managing pain, but which reduces the amount of pain and anxiety medication necessary to treat these children.").

${ }^{30}$ See, e.g., Keith Anderson, Internet Use Among College Students: An Exploratory Study, 50 J. OF AM. C. HeAlth 21 (1999); Lynette Armstrong et al., Potential Determinants of Heavier Internet Usage, 53 INT. J. OF HuM.-COMPUTER STUD. 537 (2000); V. Brenner, Psychology of Computer Use: Parameters of Internet Use,
} 
Like other forms of addiction, Internet addiction consumes the addict's time and energy, harms his personal relationships, restricts his academic, professional and social potential $^{31}$ and may result in physical problems stemming from self-negligence (lack of sleep, little exercise, malnutrition and more). ${ }^{32}$ Researchers have found that $90-95 \%$ of self-defined Internet addicts reported mild to severe distress at work, in school, and in financial matters. ${ }^{33}$ These findings are supported by a further study that reported that the use of the Internet by Internet addicts has significant negative consequences on daily life and education. ${ }^{34}$ Furthermore, researchers have explained that Internet addiction provides a false sense of achievement and connection, and replaces meaningful face-to-face relationships with virtual relationships that may impair the addict's social development. ${ }^{35}$ The negative implications of Internet addiction affect not only the addicts themselves, but also their families, employers and other social relationships that they engage in. ${ }^{36}$

\footnotetext{
Abuse, and Addiction: The First 90 Days of the Internet Usage Survey, 80 PsYCHOL. ReP. 879 (1997); Chien Chou et al., An Exploratory Study of Internet Addiction, Usage and Communication Pleasure, Paper presented at the Association for Educational Communications and Technology Annual Meeting (St. Louis, February 1822, 1998), available at http://eric.ed.gov/ERICDocs/data/ericdocs2sql/content_storage 01/0000019b/80/15/40/6d.pdf; Chien Chou, Internet Heavy Use and Internet Addiction Among Taiwanese College Students: An Online Interview Study, 4 CYBerPsychology \& BeHAVIOR 573 (2001); F. Stephen Davis et al., An Examination of Internet Usage on Two College Campuses, 33 C. Student J. 257 (1999); Diagnostic \& Statistical Manual of Mental DISORDERS (4th ed., 1994); Janet Morahan-Martin and Phyllis Schumacher, Gender, Internet and Computer Attitudes and Experiences, 17 Computers In Human Behavior 95 (2001); Helen Petrie and Davide Gunn, Internet "Addiction": the Effects of Sex, Age, Depression \& Introversion, Paper presented at the British Psychological Society London Conference (December 15, 1998); Mark E. Pratarelli \& Blaine L. Browne, Confirmatory Factor Analysis of Internet Use and Addiction, 5 CYBERPSYCHOLOGY \& BEHAVIOR 53 (2002); Nathan A. Shapira et al., Psychiatric Features of Individuals with Problematic Internet Use, 57 J. OF AFFECTIVE DISORDERS 267 (2000).

${ }^{31}$ See, e.g., J.J. Kandell, Internet Addiction on Campus: The Vulnerability of College Students, 1 CYBERPYCHOLOGY \& BEHAVIOR 11 (1998); T. Eppright \& Allwood et al., Internet Addiction: A New Type of Addiction, 96 Missouri MEDICINE 133 (1999).

${ }^{32}$ Kimberly Young, What Makes the Internet Addictive: Potential Explanations for Internet Use, Paper presented at the 105th Annual Conference of the American Psychological Association, Chicago, IL (1997). ${ }^{33}$ Kimberly Young, Internet Addiction: The Emergence of a New Clinical Disorder. 1 CYBERPSYCHOLOGY AND BEHAVIOR, 237 (1996) available at http://newmedia.cityu.edu.hk/COM5108/readings/newdisorder.pdf.

${ }^{34}$ Chien Chou, Internet Heavy Use and Internet Addiction Among Taiwanese College Students: An Online Interview Study, 4(5) CYBERPSYCHOLOGY \& BEHAVIOR 573 (2001).

${ }^{35}$ See, e.g., Robert W. Kubey et al., Internet Use and Collegiate Academic Performance Decrements: Early Findings, 51 J. Comm. 366 (2001); Robert Kraut et al., Internet Paradox: A Social Technology that Reduces Social Involvement and Psychological Well-being, 53 AM. PsYCHOLOGIST 1017 (1998).

${ }^{36}$ Anderson, supra note 30, at 21; Brenner, supra note 30, at 885; Chien Chou \& Ming-Chun Hsiao, Internet Addiction, Usage, Gratification, and Pleasure Experience: The Taiwan College Student's Case, 35 COMPUTERS \& EDUC. 65 (2000).
} 
Internet addiction is a cross-culture syndrome and the amount of time the user spends online is its best predictor. A number of studies indicate a significant correlation between the amount of time spent surfing the Internet and the risk of developing Internet addiction amongst American college students, ${ }^{37}$ Chinese, ${ }^{38}$ Taiwanese, ${ }^{39}$ Internet users from Pakistan, ${ }^{40}$ and Australian students. ${ }^{41}$ An opposite result was found in a study of Italian Internet users. ${ }^{42}$

A number of studies have tracked the frequency of Internet addiction. In a study of 1,078 college students, it was found that $9.8 \%$ of the subjects possessed characteristics consistent with Internet addiction diagnoses ${ }^{43}$. Similar results were found in a study of 576 students, revealing a $9.26 \%$ addiction rate. ${ }^{44}$ However, a conservative research study conducted using double diagnoses characteristics (Diagnostic Questionnaire - DQ and Internet Related Addictive Behavior Inventory - IARBI), found a $6 \%$ addiction rate. ${ }^{45}$ These results were further reinforced by the result of a nationwide survey of 17,251 Internet users visiting abcnews.com, which indicated a $6 \%$ addiction rate. ${ }^{46}$

While many negative side effects result from Internet addiction, it seems that addiction to virtual worlds is a far more serious problem. Research conducted of 3,989 users of the virtual world Everquest.com indicated that $15.4 \%$ of the subjects reported experiencing symptoms of withdrawal when not able to use the virtual world, $23.8 \%$ experienced mood modification while using the virtual world, $28.8 \%$ used the virtual world even when they did not enjoy the experience, and $18.4 \%$ reported problems in academics, health, finances or

\footnotetext{
${ }^{37}$ Brenner, supra note 30, at 886; Morahan-Martin \& Schumacher, supra note 30, at 106.

${ }^{38}$ Guo Liang, Surveying InTERnet Usage AND IMPACT In Twelve Chinese Cities 22-24 (2003).

${ }^{39}$ Sunny S.J. Lin \& Chin-Chung Tsai, Sensation Seeking and Internet Dependence of Taiwanese High School Adolescents, 18 COMPUTERS IN HUMAN BEHAVIOR 411 (2002).

${ }^{40}$ Kausar Suhail \& Zobia Bargees, Effects of Excessive Internet Use on Undergraduate Students in Pakistan, 9 CYBERPSYCHOLOGY \& BEHAVIOR 297 (2006).

${ }^{41}$ Wei Wang, Internet Dependency and Psychosocial Maturity Among College Students, 55 InT’L. J. OF HUMAN-COMPUTER STUD. 919 (2001).

${ }^{42}$ Ferraro Giovanni, Internet Addiction Disorder: An Italian Study, 10 CYBERPSYCHOLOGY \& BeHAVIOR 170 (2007)

${ }^{43}$ Armstrong et al., supra note 30 , at 10 .

${ }^{44}$ Kubey et al., supra note 35, at 372.

${ }^{45}$ Brenner, supra note 30 at 885.

${ }^{46}$ David N. Greenfield, Psychological Characteristics of Compulsive Internet Use: A Preliminary Analysis 2 CYBERPSYCHOLOGY \& BEHAVIOR 403, 410 (1999).
} 
relationships. ${ }^{47}$ A follow-up survey of 2,237 MMORPG users concluded that $40.7 \%$ of the subjects considered themselves addicted to the game experience. ${ }^{48}$

Additional research concluded that "excessive use" of computer games is more common among MMORPG players. ${ }^{49}$ In an interview the same year, Dr. Maressa Orzak of McKleen hospital in Massachusetts estimated, relying on survey data, ${ }^{50}$ that $40 \%$ of the 8.5 million users of the virtual world WorldOfWarcraft.com are addicted to this virtual world. ${ }^{51}$ A study of the users of the virtual world SecondLife.com ("Second Life"), revealed that subjects using this virtual world over 30 hours a week reported that on a scale of 1 - non addict to 4 - addict, they rated themselves a $3 .{ }^{52}$ Overall, $40 \%$ of users consider themselves addicts. ${ }^{53}$ Moreover, $43 \%$ of the MMORPG players reported playing between 21-40 hours a week, compared with $38 \%$ of Internet users which are not MMORPG players, that reported using the Internet for 1-2 hours a week. ${ }^{54}$

Dr. Jeffrey Michael Parsons, in his 2005 study of MMORPG's as facilitators of developing Internet addiction writes:

The findings from this study indicate that Internet addiction has a strong social foundation for MMORPG players. Internet addictive behaviors appear to be compensatory, meeting needs for companionship and empowerment in relationships. Attempts at meeting social needs through MMORPG appear to come at a cost. With the average MMORPG player spending 35

\footnotetext{
${ }^{47}$ Nick Yee, Ariadne - Understanding MMORPG Addition, NickYee.com (Oct. 2002), http://www.nickyee.com/hub/addiction/home.html (last visited October 27, 2010).

${ }^{48}$ Nick Yee, The Daedalus Project: Addiction, NickYee.com (Jul. 9, 2004), http://www.nickyee.com/daedalus/archives/000818.php (last visited October 27, 2010).

${ }^{49}$ Jeffrey Michael Parsons, An Examination of Massively Multiplayer Online Role-Playing Games as a Facilitator of Internet Addiction, Iowa Research Online.edu (2005),

http://ir.uiowa.edu/cgi/viewcontent.cgi?article=1283\&context=etd (last visited November 1, 2010).

${ }^{50}$ See, e.g., Nick Yee, The Daedalus Project: MMORPG Research, Cyberculture, MMORPG Psychology,

NickYee.com (2006), http://www.nickyee.com/daedalus/ (last visited October 27, 2010).

${ }^{51}$ Expert: 40 Percent of World of Warcraft Players Addicted, TomsHardware.Co.UK, (August 8, 2006), http://www.tomshardware.co.uk/world-of-warcraft-players-addicted-uk,review-29083.html (last visited October 27, 2010).

52 Jelle Attema \& David de Nood, Second Life: The Second Life of Virtual Reality, EPN REPORT (Holland)

(December 2006), available at https://docs.rice.edu/confluence/download/attachments/5111868/EPN-REPORTThe Second_Life_of_VR1.pdf?version=1.

${ }^{53} I \bar{d}$.

${ }^{54}$ Brian D. Ng \& Peter Wiemer-Hastings, Addiction to the Internet and Online Gaming, 8 CYBERPSYCHOLOGY \& BEHAVIOR 110 (2005).
} 
hours per week in leisure online activities, other aspects of life, such as school, work, and family, are likely to be affected in ways that may limit the long-term development of MMORPG players. Moreover, Internet addicted MMORPG players appear less likely than other groups of Internet addicts to receive treatment for their condition. ${ }^{55}$

In other words, while it is possible to think that Internet addiction is an unwanted Phenomenon with negative impacts only on the addict, there is reason to believe that addiction to virtual worlds is more serious and has much broader implications. This article will assume, based on research conducted in the field, that the combination of the addictive nature of virtual worlds with the psychological characteristics of minors, could cause significant problems. Several examples from popular literature brought hereinafter illustrate the danger of excessive use of virtual worlds.

A 2007 Australian news article described a 15-year-old boy who abandoned all other activity in order to play the popular MMORPG - Runescape.com. The boy's father compared his situation to that of a heroin addict. ${ }^{56}$ Additionally, CNET News quoted a player recovering from addiction to the virtual world Everquest.com as saying: "The game almost ruined my life... It was my life. I ceased being me; I became Madrid, the Great Shaman of the North. Thinking of it now, I almost cringe; it's so sad." ${ }^{57}$

There are several documented deaths as a result of fatigue due to extended and continuous use of virtual worlds. Li Syong Saup of South Korea died after using the virtual world Starcraft.com for more than 50 hours continuously. ${ }^{58}$ Kso Yan of China died after

\footnotetext{
${ }^{55}$ Parsons, supra note 49, at 124.

${ }^{56}$ Brian Quartermaine, Stress over Teen's 'Addiction', THE SUNDAY TIMES (Perth), Jul. 14,

2007, available at http://www.perthnow.com.au/news/western-australia/stress-over-teens-addiction/storye6frg13u-1111113958526.

${ }^{57}$ David Becker, When Games Stop Being Fun, Cnet News.com (April 12, 2002), http://news.com.com/21001040-881673.html (last visited October 27, 2010).

${ }^{58}$ See, e.g., Philippe Naughton, Korean Drops Dead After 50-hour Gaming Marathon, London TimES, Aug. 10 , 2005, available at http://www.timesonline.co.uk/tol/news/world/article553840.ece; S. Korean Dies After Games Session, BBC News.com (10 Aug., 2005), http://news.bbc.co.uk/1/hi/technology/4137782.stm (last visited October 27, 2010).
} 
using virtual worlds for more than 15 days continuously, during the New Year holiday. ${ }^{59}$ Another Chinese individual died after using virtual worlds for 3 days straight. ${ }^{60} \mathrm{Hu}$ Bin, a 16year-old Chinese teenager from the province Anhuvi at Lujiang County died two days after he swallowed an insecticide he brought with him to the Internet bar. ${ }^{61}$ Before Hu committed suicide he used virtual worlds at the Internet bar for 11 days straight. ${ }^{62}$ According to reports, the words "even the gods cannot save me," were written on the family door. ${ }^{63}$ Hu's father said that when $\mathrm{Hu}$ was about to die, he said: "Father, the insecticide I drank was toxic." The father asked him: "Why did you drink it if it was toxic?" and Hu replied: "I drank it because I wanted to make sure that you could not save me. I have played enough." ${ }^{64}$

Adolescents are between the highest risk age groups for the development of Internet addiction. ${ }^{65}$ Among those participating in surveys of users of virtual worlds, $84.3 \%$ were 18 years old or older and $13.7 \%$ were adolescents between the ages of 12 and $17 .{ }^{66}$ Contrary to this finding that there is a low percentage of adolescents using virtual worlds, it was indicated that $26-40 \%$ of the subjects participating in a different survey of virtual worlds users, were

\footnotetext{
${ }^{59}$ Ian Williams, Chinese Gamer Dies After 15-Day Session, VNUNet.com (Mar. 1, 2007), http://www.vnunet.com/vnunet/news/2184523/online-addict-games-himself (last visited October 27, 2010). ${ }^{60}$ Ian Thomson, Chinese Gamer Dies After Three-Day Session, VNUNet.com (Sep. 17, 2007), http://www.vnunet.com/vnunet/news/2198850/chinese-man-dies-three-days (last visited October 27, 2010); Man Dies After 3-Day Gaming Binge, CNN.com (Sep. 17, 2007), http://www.cnn.com/2007/TECH/09/17/internet.death.ap/index.html (last visited October 27, 2010).

${ }^{61}$ Shen Ying et al., The Death of a Young Online Game Player, EastSouthWestNorth.com (Mar. 4, 2006), http://www.zonaeuropa.com/20060304_1.htm (last visited October 27, 2010).

${ }^{62}$ Id.

${ }^{63} I d$.

${ }^{64} I d$.

${ }^{65}$ Stetka A. Vaclav \& Smahel David, Internet addiction as a risk factor? Analyzing online behavior among Czech adolescents, (Barcelona: European Communication Research and Education Association (ECREA), 2nd European Communication Conference Barcelona, 2008) ("The preliminary findings show that there is a negative correlation between age and the addiction score, indicating that the adolescent respondents (particularly teenagers aged 16 to 19) have a higher potential for addiction than the adult ones. Even though there is no significant difference between the age groups 12 to 15 and 16 to 19 in the addiction level, the older group exhibits higher awareness of the possible negative effects of their amount of Internet usage (according to their scores on the scale of self-perceived addiction), which means that the youngest children are potentially more vulnerable in regards to Internet addiction."); Soo Kyung Park et al., Prevalence of Internet addiction and correlations with family factors among South Korean adolescents, FAMILY THERAPY, Sept. 22, 2009, available at http://findarticles.com/p/articles/mi_6897/is_3_36/ai_n45062524/?tag=content;coll.

66 Parsons, supra note 49.
} 
under the age of $18 .{ }^{67}$ In yet another survey of 2,439 virtual world users it was indicated that 20.4\% were adolescents. ${ }^{68}$ These findings clearly confirm that there is a considerable population of minors using virtual worlds.

In a comparison of adult and adolescent users of the virtual world Everquest.com, a survey concluded that the younger the player is, the more hours he spends in the virtual world each week. ${ }^{69}$ Adolescents preferred violence in the virtual world significantly more than adults preferred violence. ${ }^{70} 80 \%$ of the subjects surveyed admitted that they are sacrificing something for use of the virtual world. Adults tended to admit to sacrificing social events while adolescents tended to admit to sacrificing study and work. $20 \%$ claimed they sacrifice sleep in order to use the virtual world. ${ }^{71}$

In a survey of young Italian Internet users it was concluded that these users are at a higher risk for Internet addiction than adults. ${ }^{72}$ Finally, research demonstrates that the younger the user is, the more he tends to be addicted to the use of virtual worlds. ${ }^{73}$

\section{BLURRING OF BOARDERS}

Comprehensive research has been conducted regarding the blurring of borders between reality outside the video game and reality inside the video game, especially concerning violence in video games and its effect on violent behavior outside of the game. This article assumes not only that the effects on behavior found in video game players is also found in virtual worlds users, but that the influences of virtual reality generated by the virtual world are more far-reaching and penetrate deeper layers of the users.

\footnotetext{
${ }^{67}$ M. D. Griffiths et al., Online Computer Gaming: A Comparison of Adolescent and Adult Gamers, 27 J. ADOLESCENCE 87 (2004).

${ }^{68}$ Nick Yee, Gender and Age Distribution, NickYee.com (2001), http://www.nickyee.com/daedalus/archives/000194.php (last visited October 27, 2010).

${ }^{69}$ Griffiths et al., supra note 67 , at 88 .

${ }^{70} \mathrm{Id}$.

${ }^{71} I d$.

${ }^{72}$ Giovanni, supra note 42, at 174.

${ }^{73}$ David Smahel et al., Playing MMORPG: Connections Between Addiction and Identifying with Character, 11 CYBERPSYCHOLOGY \& BEHAVIOR 715 (2008).
} 
It is assumed that the blurring of borders between the virtual world and the real world might influence behavior in the real world. Six professional organizations in the health field ${ }^{74}$ found a connection between video games and behavior in minors: stating that more than 1000 studies point overwhelmingly to a causal connection between media violence and aggressive behavior in some children. ${ }^{75}$

It was speculated that violent video games are more alarming than violent television and movies, because the player identifies with the character in the game and actively participates, albeit virtually, in the violence. ${ }^{76}$

On the contrary, some research has demonstrated that the connection between video games and violence among children is marginal, ${ }^{77}$ and that there are creative and social benefits to video games. ${ }^{78}$ Therefore, it is impossible to say unequivocally that violent video games necessarily encourage violence. Nonetheless, one cannot ignore the concern that this influence does actually exist.

Reference to these concerns is provided in the important work of Lieutenant Colonel Dave Grossman who examined the increase in the readiness of United States soldiers to shoot enemy soldiers $-20 \%$ showing such readiness to $90 \%$ showing such readiness - in the period

\footnotetext{
74 The American Psychological Association, the American Academy of Pediatrics, the American Academy of Child and Adolescent Psychiatry, the American Medical Association, the American Academy of Family Physicians, and the American Psychiatric Association.

${ }^{75}$ Am. Acad. of Pediatrics, Joint Statement on the Impact of Entertainment Violence on Children:

Congressional Public Health Summit (Jul. 26, 2000), available at

http://www.aap.org/advocacy/releases/jstmtevc.htm ("At this time, well over 1000 studies - including reports from the Surgeon General's office, the National Institute of Mental Health, and numerous studies conducted by leading figures within our medical and public health organizations - our own members - point overwhelmingly to a causal connection between media violence and aggressive behavior in some children. The conclusion of the public health community, based on over 30 years of research, is that viewing entertainment violence can lead to increases in aggressive attitudes, values and behavior, particularly in children.").

${ }^{76}$ Craig A. Anderson \& Karen E. Dill, Video Games and Aggressive Thoughts, Feelings, and Behavior in the Laboratory and in Life, 78 J. PERSONALITY \& SOC. PSYCHOL. 772, 788 (2000) ("In a sense, violent video games provide a complete learning environment for aggression, with simultaneous exposure to modeling, reinforcement, and rehearsal of behaviors. This combination of learning strategies has been shown to be more powerful than any of these methods used singly.").

${ }^{77}$ See, e.g., Ian Williams, US Teen Violence Study Exonerates Video Games, VNUNet.com (Mar. 6, 2007), http://www.vnunet.com/vnunet/news/2184836/link-video-games-violent-teens (last visited October 27, 2010); Brad Wright, Sounding the Alarm on Video Game Ratings, CNN.com (Feb. 18, 2004), http://edition.cnn.com/2002/TECH/fun.games/12/19/games.ratings/ (last visited October 27, 2010).

${ }^{78}$ Jeanne B. Funk, Reevaluating the Impact of Video Games, 32 CLINICAL PEDIATRICS 86 (1993).
} 
between World War II and the Vietnam War. ${ }^{79}$ This impressive result was achieved by using simulators performing simulations very similar to those seen in video games marketed to youth. In his further writing, Grossman discusses the actions of the shooter at the Paduka School in Kentucky. ${ }^{80}$ In that shooting, a child with no training in weapons, but with meaningful experience playing video games, caused 8 head and chest injuries in 8 different victims after shooting only 8 or 9 shots. ${ }^{81}$ This is a remarkable display of accuracy that even amazed the police. ${ }^{82}$ The shooter also conducted the shooting in a way, which, according to Grossman, contradicts the natural tendency to empty the magazine on the target perceived as the biggest threat. ${ }^{83}$ Instead, the shooter shot once at each victim before moving to the next victim, a method that is successful in video games. ${ }^{84}$

An additional situation that raised concerns about the possible negative influence of video games is the game "Doom," released by id Software in 1993. The game became popular among video games players for being one of the first games providing a 3dimensional environment. ${ }^{85}$ On April 20, 1999, two Columbine High School students committed one of the most lethal shooting assaults in American history. ${ }^{86}$ In the investigation after the shooting, officials revealed that the two youngsters were obsessive players of Doom, ${ }^{87}$ and that in a video made before the shooting, one of the boys had said, "It's going to

\footnotetext{
${ }^{79}$ See generally, Dave Grossman, On Killing: The Psychological Costs of Learning to KiLl in War AND SOCIETY (1995).

${ }^{80}$ Gunfire Inside a School Kills 3 and Wounds 5, N.Y TIMES, December 2, 1997, available at http://www.nytimes.com/1997/12/02/us/gunfire-inside-a-school-kills-3-and-wounds-5.html (The Heath High School shooting occurred at Heath High School in West Paducah, Kentucky, United States, on Monday December 1, 1997. Fourteen-year-old Michael Carneal opened fire on a group of praying students killing 3 young women, injuring four young women, and wounding one young man).

${ }^{81}$ Dave Grossman \& Gloria Degaetano, Stop Teaching OUR Kids to Kill: A Call to Action Against TV, MOVIE, \& VideO GAME ViOLENCE 4 (1999).

${ }^{82} I d$.

${ }^{83} \mathrm{Id}$.

${ }^{84} \mathrm{Id}$.

${ }^{85}$ See, e.g., Doom Description, Mobygames.com (Dec. 10, 1993) http://www.mobygames.com/game/doom (last visited October 27, 2010); Mike Watson \& Andrew Stine, Ten Years of Doom, Doomworld.com (2003), http://www.doomworld.com/10years/ (last visited October 27, 2010).

${ }^{86}$ Columbine Survivors Mark 7th Anniversary, UNITED PRESS INTERNATIONAL, Apr. 20, 2006, available at http://www.accessmylibrary.com/coms2/summary_0286-14946293_ITM (last visited October 27, 2010).

${ }^{87}$ Matt Bai, Anatomy of a Massacre, Newsweek, May 3, 1999, at 24.
} 
be like fucking Doom!" 88 The parents of the victims filed a lawsuit against video games manufacturers and movie companies. The suit was dismissed on the basis of free speech found in the First Amendment of the United States Constitution. ${ }^{89}$

Drawing an analogy between video games and virtual worlds, it is possible to assume a similar "spill over" of the virtual world reality into real life. Furthermore, while with video games it is possible to see an influence on behavior (such as increased violence), in the case of virtual worlds, thinking and dreaming are affected. Research conducted among MMORPG users, revealed that $50 \%$ of the subjects agreed that they often think of situations from the game while not online. ${ }^{90}$ In a comprehensive study of the MMORPG "Everquest," $80.6 \%$ of the women and $58.4 \%$ of the men reported dreaming of the virtual world or dreaming of themselves within the virtual world environment. ${ }^{91}$

An example of the blurring of borders can be found in a newspaper article about Korean girls engaging in sex-related conversation with a man in a chat room. ${ }^{92}$ The man was asked to reward the girls with expensive Avatar gifts (dresses, jackets and other accessories) intended for use in decorating the girls' Avatars. ${ }^{93}$ After the incident was revealed, one of the girls, a 15-year-old, said: "I don't understand why it [virtual prostitution] is bad at all?! It is not real, you know!"94

A comprehensive study of Second Life, examining comparisons between the quality of life experienced in the virtual world and the quality of life in the real world, considering time spent by the subject using the virtual world, revealed that the longer the subject used the

\footnotetext{
${ }^{88}$ Nancy Gibbs \& Timothy Roche, The Columbine Tapes, TIME, Dec. 20, 1999, at 40.

${ }^{89}$ Sanders v. Acclaim Entm't, Inc., 188 F. Supp. 2 d 1264 (D. Colo. 2002).

${ }^{90}$ David Smahel et al., MMORPG Playing of Youths and Adolescents: Addiction and its Factors, VANCOUVER: ASSOCIATION OF INTERNET RESEARCHERS (2007), available at http://www.muni.cz/research/publications/726643.

${ }^{91}$ Nick Yee, The Norrathian Scrolls: A Study of Everquest, Nick Yee.com (2001), http://www.nickyee.com/eqt/home.html (last visited October 27, 2010).

${ }^{92}$ Lee Ook \& Shin Mincheol, Addictive Consumption of Avatars in Cyberspace, 7 CYBERPSYCHOLOGY \& BEHAVIOR 417 (2004).

${ }^{93}$ Id.

${ }^{94} \mathrm{Id}$.
} 
virtual world, the more they reported that Second Life offers them a better life experience than their real life. ${ }^{95}$ Of the subjects using Second Life at least 30 hours a week, $30 \%$ agreed that Second Life offers them a better life experience than the real world. ${ }^{96}$ It is important to note that the fact that these users favorable compare the virtual world of Second Life and the real world, even though Second Life lacks many characteristics of the real world, indicates clearly that the border between the real world and the virtual world are blurred.

In this context, psychologists have warned that permanent exposure to virtual reality could change the way people comprehend the real world: "Conscious reality changes as the software of everyday life changes, and remains changed thereafter. Whether it's watching the tube, surfing the web, or viewing the latest special-effects flick, chronic exposure to simulated ideas, moods, and images conditions your sensibilities, albeit to different degrees, for how the real world should look, how fast it should go, and how you should feel when living in it." ${ }^{97}$ Critics of virtual reality are afraid that a growing number of people will prefer the experience of virtual reality to the real one. ${ }^{98}$ Why show others a real flaccid body when one can interact online using a beautiful and sexy Avatar? Why bother with boring real life while in the virtual world a man can fly through the air, experience remote adventures, and build a house or even a city in any shape he likes $?^{99}$

In the physiological context it has been explained that, while it is generally accepted that the brain structure is completed during early childhood, this fact only applies to the cognitive parts of the brain. ${ }^{100}$ Babies, like adults, have many synaptic ties between nerve cells in the cognitive regions, but babies between the ages of 1 and 2 years have double the

\footnotetext{
${ }^{95}$ Attema, supra note 52, at 34.

${ }^{96}$ Id.

${ }^{97}$ Richard DeGrandpre, Great Escape, 9 ADBUSTERS 2 (Mar.-Apr. 2001) at 23.

${ }^{98}$ See, e.g., Edward Castronova, Fertility and Virtual Reality, 66 WASH. \& LEE L. REV. 1085 (2009); Science Clarified, Virtual Reality, Scienceclarified.com (2010) http://www.scienceclarified.com/scitech/VirtualReality/index.html (last visited October 27, 2010).

${ }^{99}$ Science Clarified, supra note 98.

${ }^{100}$ Barbara Strauch The Primal Teen: What the New Discoveries About the Teenage Brain Tells Us ABOUT OUR KIDS 19-21 (Bantam Books 2004).
} 
synaptic ties of adults. ${ }^{101}$ During childhood, when the basic understanding or the world structuring of the child develops, the amount of synapses are diminished to fit adults levels. ${ }^{102}$ Research indicates that in the years of sexual maturation, similar synapse prosperity exists in the frontal cortex of the brain, the area responsible for judgment and inhibition, but that these synapses similarly diminish to adult levels following sexual maturation. ${ }^{103}$ In both cases, the synapses that survive are those reinforced by environmental interaction. ${ }^{104}$ In light of these findings, it is possible to estimate that minors in the years of sexual maturation who interact with the environment using virtual reality, will form a system of judgment and inhibition that is different from the one that would have been formed without the use of information technologies. These minors may then carry this system, adapted to the virtual world but not to the real one, throughout their entire life.

\section{Current Law}

\section{INTRODUCTION}

The damages that might be caused to minors by the use of virtual worlds, as detailed in the previous chapter, necessitate an examination of the regulation of minors entering these worlds. Such regulation is possible through several different means: Technology (Code and Architecture); The Market (Financial Incentives); Social Regulation (Practical Values and Pressure) and Law (Legislation and Litigation). ${ }^{105}$

Legal regulation is not necessarily a call for governments to develop laws imposing tort, contract, or other liability on the virtual worlds companies and/or forcing these companies to prevent the dangers of virtual world use to children. Regulation can be, in some

\footnotetext{
${ }^{101} I d$.

${ }^{102} I d$.

${ }^{103} I d$.

${ }^{104}$ Peter R. Huttenlocher \& Arun S. Dabholkar, Regional Differences in Synaptogenesis in Human Cerebral Cortex, 387 J. Comp. Neurology 167, 176-77 (1997).

${ }^{105}$ See, e.g., LAWRENCE LESSig, CODE AND Other LAWS OF CYBERSPACE (1999).
} 
instances, performed through the provision of non-legal guidance that does not require involvement by the legislature, does not limit the new information technology, and has been argued to be more effective than enacting legislation. ${ }^{106}$

In the field of technology, it is possible to integrate built-in mechanisms that follow the online habits of users (a mechanism made possible by the current terms of service ${ }^{107}$ and not free of privacy problems $)^{108}$ and use this information to prevent excessive danger while in virtual worlds. However, this regulation seems contradictory to the natural dynamic of technology, which strives to innovate and develop "stronger" and "better" functions, and add new dimensions and senses to the technological experience. This will only amplify the users' addiction to the information technology and the blurring of borders between reality and virtual reality. Reinforcement of information technology in this way, and not its restraint, is the "natural" purpose of the technology developers, especially those working for virtual worlds companies, who seek to break borders and make new developments in the field, and are operating according to economic interests. ${ }^{109}$ For these reasons, it seems that selfregulation by technology will not promote the goals of said regulation.

Market forces also do not constitute a sufficient regulator in this case. On the contrary, the company manufacturing each virtual world has an economic interest in

\footnotetext{
${ }^{106}$ The Coase Theorem maintains that when the transaction cost is zero, a change in the liability laws will not effect the allocation of resources. For example, if the law imposes liability on a cattle grower for the damages his cattle caused passing through his neighbor's corn field, it will create more incentive for the cattle grower to invest in a means to control cattle passage than the money he will receive from the corn grower to purchase these means. Ronald Coase, The Problem of Social Cost, 3 J.L \& ECON. 1 (1960). This means that legal regulation is not necessarily more effective then non-legal regulation. This theorem was tested on cattle growers. ROBERT C. ElLICKSON, ORDER Without LAW: How NeIGHBORS SETTLE DisPutes (1991). It was found that neighbors tend to cooperate but they achieve cooperative results not by bargaining on legal rights, as the theorem predicts, but by developing and enforcing maladaptive norms of neighboring which defeat formal legal rights. Id.

${ }^{107}$ See, e.g., EverQuest Terms of Service, Clause II(D), Soe.com, http://www.soe.com/en/termsofservice.vm (last visited October 27, 2010) (allowing monitoring the user computer for the purpose of improving the service and preventing the running of deception software); See also id. at Clause III(E1) (allowing identifying minor user computer by attaching cookies or by other technological means).

${ }^{108}$ See Tal Z. Zarsky, Information Privacy in Virtual Worlds: Identifying Unique Concerns Beyond the Online and Offline Worlds, 49 N.Y. L. SCH. REV. 231 (2004).

${ }^{109}$ See CASTRONAVA, supra note 28 at 65.
} 
encouraging as many users as possible to stay as long as possible in the virtual world. ${ }^{110}$ In other words, for each company, a good costumer is an addicted one. Therefore, as long as there are no market incentives for the company to limit a user's online time, to prevent or decrease addiction, or to warn of the dangers and try to prevent them, one cannot expect market forces to encourage harm prevention in the use of virtual worlds.

An additional means of regulation could be society and social values. Two types of societies are relevant: the virtual and the tangible. In Second Life, the user agrees by the Terms of Service to abide by the Community Standards. ${ }^{11}$ According to this document, the user must treat other users with tolerance, not bother or offend others, and maintain privacy and order. ${ }^{112}$ This document contains no warning about Internet addiction or borders between real and virtual worlds. Additionally, at this time, there seems to be no socially constructed rules in virtual worlds aimed at preventing addiction or requiring virtual worlds companies to take action to prevent addiction or other damages to users.

In the tangible world the picture is more complicated. Communities hurt by virtual worlds damage, like those including parents whose children committed suicide, respond by creating pressure for tighter supervision of children, ${ }^{113}$ despite the fact that there could be difficulties with such supervision. ${ }^{114}$ In light of the limited supervision capabilities in the virtual world, and in light of the failure of many families in the western world to limit

\footnotetext{
${ }^{110} I d$.

${ }^{111}$ Community Standards, Welcome to Second Life World, Secondlife.com, http://secondlife.com/corporate/cs.php (last visited October 27, 2010). Ontario. In October 2008, Brandon's parents were so frustrated with their son's 'Call of Duty 4' addiction that they took away his game system. On November 5, 2008 his body was found. An autopsy report says he died of injuries to his chest after falling out of a tree. The article cited Stephen Kline, a researcher with Simon Fraser University who has studied youth and compulsive gaming, saying the sad ending to Brandon's life will make it difficult for parents to act if they see their children growing increasingly preoccupied with gaming: "Coming out of this, I think a lot of parents will say, 'Well, what can I do? I can't take the game away. I think my kid will do a bump,"' he said. "There's a deep lack of information about what to do.").
} 
computer access, it is difficult to locate an existing effective control and surveillance mechanism that protects against addiction and distinguishes the borders between the virtual and the tangible. Therefore, in light of the aforementioned lack of capabilities of the market, technology and society regulators to prevent excessive use, addiction and blurring of borders among minors and its negative implications, the question arises as to whether and how minors' use of virtual worlds should be regulated. This raises another question as to whether and how we should use the law for the purpose of this regulation.

Reinforcement of the need to answer these questions can be found in the calls for regulation of virtual worlds in light of the potential damages widely detailed in the previous chapter. In the United Kingdom, Lord Trisman, a minister in the government, urged the managers of virtual worlds companies to take seriously the Phenomenon of addiction and begin better policing virtual worlds. ${ }^{115}$ Similarly, in the United States, Congressman Mark Kirk recently called on the Federal Trade Commission to activate a "Parents Alert" regarding Second Life. ${ }^{116}$ Congressman Kirk, however, referred to the Phenomenon of online predators and not to the Phenomena discussed in this article. Nonetheless, the message is clear.

Therefore, in order to analyze the proper legal solution proposed in the next chapter, one must first understand the current situation. The following section examines California's current law regarding recovery by minors for damages from the use of virtual worlds. The following section also examines the current law in China, where legislation has been enacted to prevent these kinds of damages. It should be emphasized that the current law in California within this context is tort law, is not unique to virtual worlds, and provides ex-post remedies that are meant to compensate the victim, restoring the victim to his or her position prior to the

\footnotetext{
115 Joe Fay, UK Minister Pledges Policing for Second Life, THE REGISTER (UK), Oct. 26, 2007, available at http://www.theregister.co.uk/2007/10/26/virtual_worlds/.

${ }^{116}$ GamePolitics.com, More on Congressman's Campaign to Regulate Second Life, Gamepolitics.com, http://www.gamepolitics.com/2008/05/12/more-on-congressmans-campaign-to-regulate-second-life (last visited October 27, 2010) (Quoting Congressman Kirk: "Parents should be worried about one of the fastest growing websites on the planet called Second life. It's the next level up from MySpace, a fully interactive 3-D experience...I'm worried that they don't properly screen for children.").
} 
damages suffered. In China, the regulation is fact-based and is deals with preventing the damages ex-ante.

First, I will examine the question of whether the injured minor's parents have a cause of action in tort for negligence and/or manufacturer's liability against virtual worlds companies. Next, if there is a cause of action, I will examine the liability waiver ${ }^{117}$ in the Terms of Service contract between the user and the company operating the virtual world. ${ }^{118}$ On this note, it is important to mention that for minors who are not capable to contract without the consent of their parents or guardian we can conclude that the Terms Of Service have no relevance. ${ }^{119}$ Additionally, I will examine the defenses that exist for virtual worlds companies on two levels: 1) examination of the immunity given to Internet service providers in the Communication Decency Act, and 2) constitutional immunity based on the First Amendment freedom of speech. Finally, I will examine parents' liability for their children's injuries in this context and the attempts at regulation in China.

\footnotetext{
${ }^{117}$ See e.g., Second Life Terms of Service, Clause 10.1, Secondlife.com, http://secondlife.com/corporate/tos.php\#tos10 (last visited October 27, 2010); EverQuest Terms of Service, Clause VIII, Soe.com, http://www.soe.com/en/termsofservice.vm $\% 22 \% 20 \% 5 \mathrm{Ct} \% 20 \% 22$ blank\#n 8 (last visited October 27, 2010); Club Penguin Terms of Use, Clause 3, Clubpenguin.com, http://www.clubpenguin.com/terms.htm (last visited October 27, 2010).

${ }^{118}$ In their more common name, EULA - End User License Agreement. For a general criticism of EULA's, see, e.g., Joshua A.T. Fairfield, Anti-Social Contracts: The Contractual Governance of Virtual Worlds, 53 MCGILL L. J. 427 (2008), available at http://lawjournal.mcgill.ca/documents/Fairfield.pdf; Brendan James Gilbert, Getting to Conscionable: Negotiating Virtual Worlds' End User License Agreements Without Getting Externally Regulated, 4 J. InT’L Com. L. \& TeCH. 238 (2009); Joshua A.T. Fairfield, Virtual Property, 85 B.U. L. ReV. $1048,1082(2005)$.

${ }^{119}$ CAL. CIV. CODE $\S 1556$ ("All persons are capable of contracting, except minors, persons of unsound mind, and persons deprived of civil rights."); See also Joseph I. Rosenbaum, Virtual Worlds: Virtual Worlds for Children: Part One, 10 ECOMMERCE L. \& POLICY (January 2008) ("Given that the age of capacity for the purposes of UK contract law is 18 year of age, it is questionable whether a virtual world operator would be able rely on these warranties and indemnities when contracting with minors. The general rule at common law is that a minor's contracts are voidable at his or her option.").
} 


\section{THE LAW IN CALIFORNIA}

United States courts have heard and ruled in many cases concerning the liability of publishers, producers, and manufacturers of journals, ${ }^{120}$ music, ${ }^{121}$ television shows, ${ }^{122}$ role playing games, ${ }^{123}$ movies, ${ }^{124}$ and video games, ${ }^{125}$ for the injuries caused to the users themselves or to third parties injured by the users. ${ }^{126}$ The three major issues arising in these cases, especially those involving video games, were: 1) the absence of liability in light of remote foreseeability and/or causation; 2) the absence of strict liability for defective product and/or failure to warn, because courts differentiate between the ideas and messages in the

\footnotetext{
${ }^{120}$ Herceg v. Hustler Magazine, Inc., 565 F. Supp. 802, 803 (S.D. Tex. 1983) ("inflammatory article on the practice of 'autoerotic asphyxiation").

${ }^{121}$ See, e.g., McCollum v. Columbia Broad. Sys., Inc., 249 Cal. Rptr. 187 (Cal. Ct. App. 1988) (plaintiffs filed suit alleging that Ozzy Osbourne's song, "Suicide Solution", caused a child to commit suicide); Davidson v. Time Warner, Inc., No. Civ.A.V-94-006, 1997 WL 405907 (S.D. Tex. Mar. 31, 1997) (holding that it was unforeseeable to producers of rap music that by distributing 2Pacalypse Now, which contained a song about "cop killing", a person would kill a police officer).

${ }^{122}$ See, e.g., Zamora v. Columbia Broad. Sys., 480 F. Supp. 199 (S.D. Fla. 1979) (plaintiff filed suit alleging that his exposure to television violence caused him to become "desensitized to violent behavior," to develop a "sociopathic personality," and to kill his eighty-three-year-old neighbor); Sakon v. Pepsico, Inc., 553 So. 2d 163, 166 (Fla. 1989) (holding that it was unforeseeable that a child would imitate a stunt in a commercial); DeFilippo v. Nat'l Broad. Co., Inc., 446 A.2d 1036 (R.I. 1982) (where the plaintiff's son hanged himself after watching a stunt performed on "The Johnny Carson Show"); Olivia N. v. Nat'l Broad. Co., Inc., 178 Cal. Rptr. 888 (Cal. Ct. App. 1982) (where the plaintiff was raped with a bottle by juveniles allegedly acting upon the stimulus of observing an "artificial rape" scene in a television drama); Walt Disney Prod., Inc., v. Shannon, 276 S.E.2d 580 (Ga. 1981) (where a child was injured trying to reproduce a sound effect demonstrated on a television program by rotating a BB inside an inflated balloon).

${ }^{123}$ Watters v. TSR, Inc., 904 F.2d 378 (1990) (where a user of "Dungeons \& Dragons" game committed suicide). For an analysis of criminal cases, see State v. Molitor, 729 S.W. 2 d 551 (Mo. Ct. App. 1987) (where a young woman was tied up and strangled after an all night house-party devoted to listening to music, consuming liquor, smoking marijuana and practicing martial arts, the defendant sought to introduce expert testimony suggesting that he had been "desensitized" at some point by playing Dungeons \& Dragons); People v. Ventiquattro, 527 N.Y.S.2d 137 (App. Div. 1988) (a fifteen-year-old boy who killed a companion with a shotgun gave the police several conflicting accounts of how the shooting occurred, including one account in which he stated that he was playing the game Dungeons \& Dragons and shot the victim while fantasizing that it was his job to exterminate evil).

${ }^{124}$ See Bill v. Superior Court, 187 Cal. Rptr. 625 (Cal. Ct. App. 1982) (First Amendment concerns required entry of summary judgment for defendants, producers of a violent movie, in lawsuit brought on behalf of girl shot outside a theater where defendants' movie was shown); Byers v. Edmondson, 712 So. 2d 681 (La. Ct. App. 1998) (where a shooting victim brought negligence and intentional tort claims against the directors, producers, and distributors of the movie, "Natural Born Killers", and alleged that the shooter "went upon a crime spree... as a result of seeing and becoming inspired by the movie...").

${ }^{125}$ See James v. Meow Media, Inc., 90 F. Supp. 2d 798 (W.D. Ky. 2000) (families of the victims that died in the Heath High School shooting alleged that video games, movies, and Internet sites motivated the murderer to commit the killing); Wilson v. Midway Games, Inc., 198 F. Supp. 2d 167 (D. Conn. 2002) (where a mother of a child killed by his friend alleged that the killer was inspired by the video game "Mortal Combat").

${ }^{126}$ See, e.g., Davidson, No. Civ.A.V-94-006, 1997 WL 405907; Olivia N., 178 Cal. Rptr. 888; Molitor, 729 S.W. 2d 551; Ventiquattro, 527 N.Y.S.2d 137; Bill, 187 Cal. Rptr. 625; Byers, 712 So. 2d 681; James, 90 F. Supp. 2d 798; Wilson, 198 F. Supp. 2d 167.
} 
game and the product itself; and 3) immunity by virtue of the First Amendment. ${ }^{127}$ Scholars have widely criticized the approach of these courts. ${ }^{128}$

Nonetheless, despite the fact that courts have rejected all of the claims mentioned above, there are two essential differences between the cases concerning video games and cases concerning virtual worlds, each difference important enough to potentially enable tort liability. With regard to foreseeability and causation, at least concerning injuries that might be caused to users as a result of addiction to virtual worlds, companies should be unable to claim an absence of foreseeability and/or causation in light of the comprehensive research discussed in Section II. There is no dispute that excessive use of virtual worlds may cause injury. With regard to strict liability under products liability law and the immunity under the First Amendment see the discussion below.

\section{A. Cause of Action in Tort}

In this section, I will first examine the tort framework of emotional injuries that might be caused to a minor user as a result of the dangers lurking in virtual worlds. Physical injuries like suicide are a result of the emotional injuries and a broad discussion of that exceeds the scope of this article. Generally, in order to recover on a negligence claim, the plaintiff must establish: 1) that the defendant owed a duty to the plaintiff; 2) that the defendant breached

\footnotetext{
${ }^{127}$ See Bill, 187 Cal. Rptr. 625.

${ }^{128}$ See, e.g., Timothy Dylan Reeves, Note, Tort Liability for Manufacturers of Violent Video Games: A Situational Discussion of the Causation Calamity, 60 ALA. L. Rev. 519, 546 (2009) ("[M]anufacturers of [video games] ... should be subject to liability for any violent acts that are caused by their games....Tort law has traditionally been slow to accept social science, in particular psychology and psychological illness.... Subjecting manufacturers to liability is the only way to ensure that video games do not train players to commit violent acts."); John Charles Kunich, Shock Torts Reloaded, 6 APPALACHIAN J. L. 1, 28 (2006) ("In the prototypical shock torts case, it is not the defendant, but the plaintiff who is in serous jeopardy of being deprived of basic human and constitutional rights.... [It has been] shown that reflexive, cut-and-paste decision-making is apt to lead to hasty and incorrect defeat for plaintiffs."); William Cross, Note and Recent Development, Hot Coffee and Freeze-Dried First Amendment Analysis: The Dubious Constitutionality of Using Private Ratings for Public Regulation of Video Games, 4 FiRST AMENDMENT L. R. 299, 341 (2006) ("Replacing reasoned legal and constitutional analysis with the gut feelings of a three-parent panel hired by the industry should leave as bitter a taste in our mouth as replacing gourmet Colombian beans with day-old gas station grounds. To pass constitutional muster, legislators must provide fresh, thoughtful First Amendment analysis instead of the strange brew they have served up thus far.").
} 
this duty; 3) that this breach caused injury to the plaintiff; and 4) that there was substantial and proximate causation. ${ }^{129}$ For the sake of the current discussion I will assume that the developers of virtual worlds owe a duty to minors using these worlds. I will further assume that, due to the direct damage caused by the use of virtual worlds as detailed above, discussion of lack of causation, which has been the main subject in cases dealing with damages to third parties caused by violent video games' users, as well as suicides caused by these games, is not relevant to the current discussion.

\section{(1) Negligent Infliction of Emotional Distress}

Liability for negligent infliction of emotional distress is defined in the Restatement (Third) of Torts as follows:

An actor whose negligent conduct causes serious emotional disturbance to another is subject to liability to the other if the conduct: (a) places the other in immediate danger of bodily harm and the emotional disturbance results from the danger; or (b) occurs in the course of specified categories of activities, undertakings, or relationships in which negligent conduct is especially likely to cause serious emotional disturbance. ${ }^{130}$

The tort of negligent infliction of emotional distress was established in the United States as an identified and independent cause of action only in the last half century. ${ }^{131}$ Before that, courts were reluctant to reward recovery for emotional distress caused by negligence. ${ }^{132}$

Today, only two states continue to withhold recovery for negligent infliction of emotional distress. ${ }^{133}$ Other states differ in the tests they apply in these causes of action. ${ }^{134}$

\footnotetext{
${ }^{129}$ See Sanders, 188 F. Supp. 2d at 1276; Leake v. Cain, 720 P. 2d 152, 155 (Colo. 1986).

${ }^{130}$ RESTATEMENT (THIRD) OF TORTS: LIABILITY FOR PHYSICAL AND EMOTIONAL HARM $§ 46$ (1998) (Tentative Draft No. 5, 2007).

${ }^{131}$ See, e.g., John J. Kircher, The Four Faces of Tort Law: Liability for Emotional Harm, 90 MARQ. L. REV. 789, 807-8 (2007) (review of the tort history); Julie A. Davies, Direct Actions for Emotional Harm: Is Compromise Possible?, 67 WASH. L. REV. 1 (1992).

${ }^{132}$ Robert J. Rhee, A Principled Solution for Negligent Infliction of Emotional Distress Claims, 36 ARIZ. ST. L.J. 805,808 (2004) ("[C]ourts are naturally wary of opening the floodgates to fraudulent, frivolous, and perhaps even marginal lawsuits.").

${ }^{133}$ See, e.g., Mechs. Lumber Co. v. Smith, 752 S.W. 2d 763, 765 (Ark. 1988); Jaynes v. Strong-Thorne Mortuary, Inc., 954 P. 2d 45, 50 (N.M. 1997).
} 
Recovery for negligent infliction of emotional distress is limited by the demand for proof of the standard quartet in tort as stated above (i.e., duty, breach of duty, cause and damage) as well as the additional demand for proof that the plaintiff is suffering from a physical injury or physical implication resulting from the negligence. ${ }^{135}$ In other words, in the absence of physical injury, there is no recovery. Few states still hold this attitude. ${ }^{136}$

Most of the states that have considered this issue ${ }^{137}$ allow for recovery for negligent infliction of emotional distress as long as the mental distress produced some physical signs of its existence. Evidence found sufficient in many jurisdictions includes loss of appetite, insomnia, nightmares about the incident, ${ }^{138}$ weight loss, inability to perform domestic chores, nervousness, extreme anger, ${ }^{139}$ and nervous breakdowns. ${ }^{140}$

In California, a state that has adopted the foreseeability burden combined with serious damages, the courts have struggled to define the border between direct damage and "bystander" damage. ${ }^{141}$ In 1989 , the California Supreme Court was forced to deal with this struggle in Marlene F. v. Affiliated Psychiatric Medical Clinic, Inc. ${ }^{142}$ In that case the plaintiff and her son had undergone family counseling with a therapist. ${ }^{143}$ The plaintiffmother claimed that the therapist had molested her son and that she suffered emotional damage from it. ${ }^{144}$ The court acknowledged her claims and demonstrated its ambition to reintegrate direct damage inflicting emotional distress into conventional negligence claims. ${ }^{145}$

\footnotetext{
${ }^{134}$ See Kircher, supra note 131 , at 809 .

${ }^{135} \mathrm{Id}$. at 810 .

${ }^{136}$ The states are Florida, Georgia, Indiana, Kansas, Kentucky and Nevada.

${ }^{137}$ Alaska, Arizona, Delaware, Idaho, Louisiana, Maryland, Massachusetts, Michigan, Minnesota, Mississippi, Missouri, Nevada, New Hampshire, North Dakota, Oregon, Pennsylvania, South Carolina, South Dakota, and Utah.

${ }^{138}$ D'Ambra v. United States, 396 F. Supp. 1180, 1183 (D. R.I. 1973).

${ }^{139}$ Daley v. LaCroix, 179 N.W. 2d 390, 396 (Mich. 1970).

${ }^{140}$ Netusil v. Novak, 235 N.W. 335, 337 (Neb. 1931).

${ }^{141}$ Molien v. Kaiser Foundation Hospitals, 616 P. 2d 813 (Cal. 1980).

${ }^{142}$ Marlene F. v. Affiliated Psychiatric Medical Clinic, Inc., 770 P. 2d 278 (Cal. 1989).

${ }^{143} \mathrm{Id}$.

${ }^{144}$ Child molestation is clearly the type of conduct one would often associate with an intentional tort. However, because the law pertaining to intentional infliction of emotional distress has been narrowly construed, a person in Marlene F.'s position would have to have been present at the time of the molestation to state a cause of action. See Restatement (SECOND) OF TORTS § 46(2) (1965). Thus, Marlene F.'s right to bring suit hinged on the
} 
In addition, California is among the few states that identify the duty to avoid negligent infliction of emotional distress even when there is no threat of physical damage. ${ }^{146}$ For example, in Molien v. Kaiser Foundation Hospitals, the California Supreme Court recognized the right of a husband to demand recovery for emotional distress resulting from of a miscommunication with a doctor who incorrectly told him that his wife had been diagnosed with several sex diseases. ${ }^{147}$ Despite the fact that the husband was not in the zone of danger for physical damage, the court classified him as a direct victim of the doctor's negligence and allowed him to sue on the basis that the damage was foreseeable and he suffered from a real and severe injury. ${ }^{148}$

California, however, eventually limited this trend. In Ochoa v. Superior Court, the California Supreme Court held that parents who had witnessed their son's illness and death as a result of an undiagnosed and untreated disease by doctors and medical staff could recover only as bystanders and not as direct victims. ${ }^{149}$ Today, the rule is that a cause of action for negligent infliction of emotional distress requires the plaintiff to demonstrate: (1) severe emotional distress; (2) caused actually and in proximity by; (3) the wrongdoing; (4) of the defendant, who should have anticipated that the wrongdoing would cause such distress. ${ }^{150}$ With regard to suicides resulting from the damages caused, courts have ruled that a cause of action should be acknowledged only if the wrongdoer brought the deceased to a point where he was under an uncontrollable urge to take his own life. ${ }^{151}$

\footnotetext{
viability of her negligence claim. As such, Justice Arguelles wrote a strong concurring opinion in Marlene F. criticizing the rigidity of the law of intentional torts. See Marlene F., 770 P. 2d at 283-88.

${ }^{145}$ Marlene F., 770 P. 2d at 280-83.

${ }^{146}$ Davis, supra note 30 , at 8.

${ }^{147}$ Molien, 616 P. $2 \mathrm{~d}$ at 813.

${ }^{148}$ Id. at $816-17$.

${ }^{149}$ Ochoa v. Superior Court, 703 P.2d 1 (Cal. 1985).

${ }^{150}$ Austin v. Terhune, 367 F. 3d 1167, 1172 (9th Cir. 2004) (quoting Brooks v. United States, 29 F. Supp. 2d 613, 617 (N.D. Cal. 1998)).

${ }^{151}$ See, e.g., Lucas v. City of Long Beach, 131 Cal. Rptr. 470 (Cal. Ct. App. 1976); Tate v. Canonica, 5 Cal. Rptr. 28 (Cal. Ct. App. 1960); Burnight v. Industrial Acc. Com., 5 Cal. Rptr. 786 (Cal. Ct. App. 1960); Daniels v. New York, N.H. \& H.R. Co., 67 N.E. 424, 426 (Mass. 1903); State ex rel. Richardson v. Edgeworth, 214 So.
} 


\section{(2) Manufacturer's Liability}

A manufacturer could bear strict liability for damages caused by a dangerous product. ${ }^{152}$ Products liability theory states that a manufacturer can reasonably anticipate damages caused by its product and, therefore, the manufacturer should bear liability for the damages created by its product. ${ }^{153}$ This liability exists regardless of the care taken in the course of manufacturing and selling of the product ${ }^{154}$ and in addition to liability under other laws, mainly under tort law. ${ }^{155}$ Nevertheless, there are certain products that cannot be manufactured as safe for their ordinary intended use. ${ }^{156}$ In order to prevent these products from being considered unreasonably dangerous, the seller is required to give instructions or warnings on the package regarding safe use. ${ }^{157}$ The warnings must sufficiently caution the user of any danger anticipated and provide steps to prevent it, while instructions must warn the user from the danger it is meant to prevent. ${ }^{158}$ A product bearing a warning, that when heeded makes the product safe to use, is not defective or unreasonably dangerous. ${ }^{159}$ Therefore, when a sufficient warning is present, the manufacturer's liability is based on negligence standards and not on strict liability.

Under negligence standards, a manufacturer's knowledge of his product's quality is absolute. ${ }^{160}$ This assumes that the manufacturer foresees unreasonable danger or injury or has

2d 579, 587 (Miss. 1968); Bogust v. Iverson, 102 N.W. 2d 228, 232 (Wis. 1960); Orcutt v. Spokane County, 364 P. 2d 1102, 1105 (Wash. 1961); Arsnow v. Red Top Cab Co., 292 P. 436, 442-43 (Wash. 1930).

152 RESTATEMENT (SECOND) OF TORTS $§ 402 \mathrm{~A} \mathrm{cmt.} \mathrm{i} \mathrm{(1965)} \mathrm{(For} \mathrm{a} \mathrm{product} \mathrm{to} \mathrm{be} \mathrm{considered} \mathrm{unreasonably}$ dangerous, it "must be dangerous to an extent beyond that which would be contemplated by the ordinary consumer who purchases it, with the ordinary knowledge common to the community as to its characteristics."); Id. at cmt. f.

${ }^{153} \mathrm{Id}$. at $\S 402 \mathrm{~A}$.

${ }^{154} I d$.

${ }^{155}$ See, e.g., RESTATEMENT (SECOND) OF TORTS $\S 402$ A cmt. a (1965) ("The rule stated here is not exclusive."); Roger J. Traynor, The Ways and Meanings of Defective Products and Strict Liability, 32 TENN. L. REV. 363, 367 (1965); Jiminez v. Sears, Roebuck \& Co., 482 P.2d 681 (Cal. 1971).

${ }^{156}$ RESTATEMENT (SECOND) OF TORTS $§ 402$ A cmt. k (1965) ("Unavoidably unsafe products. There are some products which, in the present state of human knowledge, are quite incapable of being made safe for their intended and ordinary use. These are especially common in the field of drugs...").

${ }^{157} I d$. at cmt. j.

${ }^{158}$ Boyl v. California Chem. Co., 221 F. Supp. 669, 676 n.6 (Dist. Ct. Or. 1963).

${ }^{159}$ RESTATEMENT (SECOND) OF TORTS $§ 402 A$ (1965).

${ }^{160} 2$ Fowler V. HARPER \& Fleming JAMES Jr., THE LAW OF TORTS 907 (1956). 
the ability to foresee it if he acts as a reasonable and careful person. ${ }^{161}$ In order to prove failure to warn, the plaintiff must show that the manufacturer knew or should have known about the conditions making warnings mandatory. ${ }^{162}$ Where it is found that the warning was insufficient, the product is found to be unsafe or unreasonably dangerous. ${ }^{163}$

All manufacturers are required to provide warnings of reasonably foreseeable dangers and dangers of which customers should reasonably be made aware. ${ }^{164}$ Yet, adjusting the warning requires taking into account other factors. ${ }^{165}$ There are several factors related to defining warning adjustment, which are not necessarily determinative. ${ }^{166}$ The first factor is the level of expertise of those reasonably expected to use or make contact with the product as it advances through the marketing chain. ${ }^{167}$ The second factor is the familiarity of the product to the user. ${ }^{168}$ The third factor is the nature of the individuals intended to use the product. ${ }^{169}$

In the cases mentioned above involving claims against video games manufacturers, courts have ruled that the ideas influencing the plaintiff's son to commit suicide or the video game user to injure a third party, are not a "product." A broad discussion of this issue occurred in Wilson v. Midway. ${ }^{170}$ The defendant in that case argued that the video game "Mortal Combat" is not a "product" under the Connecticut Defective Products Act, ${ }^{171}$ and that despite the fact that the term "product" is not defined in the law, it cannot be interpreted as

\footnotetext{
161 Id.

162 Marc A. Franklin, Tort Law And Alternatives 506 (2d ed. 1979).

${ }^{163}$ Borel v. Fibreboard Paper Prod. Corp., 493 F. 2d 1076, 1089 (5th Cir. 1973); Steif v. J.A. Sexauer Mfg. Co., 380 F.2d 453, 464 (5th Cir. 1976).

${ }^{164}$ Martinez v. Dixie Carriers, Inc., 529 F.2d 457, 464 (5th Cir. 1976).

${ }^{165}$ Ionmar Compania Naviera, S.A. v. Olin Corp., 666 F.2d 897, 904 (5th Cir. 1982).

${ }^{166} I d$.

${ }^{167} \mathrm{Id}$.

${ }^{168} \mathrm{Id}$.

${ }^{169}$ See, Linda M. Eckles, Note, Products Liability in a Maritime Setting: the Negligent Failure to WarnIonmar Compania Naviera, S.A. V. Olin Corp, 7 TUL. MAR. L. J. 130, 132 (1982).

${ }^{170}$ Wilson, 198 F. Supp. 2d 167.

${ }^{171}$ Conn. Gen. Stat. $\S \S 52-572 \mathrm{~m}$ et seq. See also, Robert B. Adelman \& Mary Ann Connors, The Legal Framework of a Products Liability Case in Connecticut, 67 CONN. B J. 355, 361 (1993); RESTATEMENT (THIRD) OF TORTS: PRODUCTS LIABILITY $\S 19 \mathrm{cmt}$. a (1998) ("Apart from the statutes that define 'product' for the purposes of determining products liability, in every instance it is for the court to determine as a matter of law whether something is, or is not, a product.").
} 
including ideas and expressions. ${ }^{172}$ The court divided the claims of manufacturer liability in this case into two categories: damage caused by commercial and intellectual property ${ }^{173}$ and damage caused by inspiration or "brainwashing." ${ }^{174}$ As stated, courts that have examined whether media- based incitement is a "product" for the purposes of strict liability have rejected this kind of claim. ${ }^{175}$

Contrary to video games, in which the game ideas and the cartridge can be separated, virtual worlds do not allow for such separation, as the virtual world itself is a product. ${ }^{176}$ Nonetheless, non-scripted virtual worlds designers could argue that they are not liable for the content of the virtual worlds because they did not create it. Nevertheless, in light of the research revealing the damages that might occur due to virtual worlds' use, it will be difficult for virtual world's developers to claim that they did not know that they needed to warn users of these possible damages.

\footnotetext{
${ }^{172}$ See, e.g., Winter v. G.P. Putnam's Sons, 938 F.2d 1033 (9 $9^{\text {th }}$ Cir. 1991) (mushroom enthusiasts who relied on erroneous information in encyclopedia of mushrooms had no strict liability claim against publisher when they became ill); Watters v. TSR, Inc., 904 F.2d 378, 380-381 (6 $6^{\text {th }}$ Cir. 1990) (mother of teenage boy who played Dungeons and Dragons game had no strict products liability claim against game manufacturer for son's suicide); Sanders v. Acclaim Entm't, Inc., Civ. No. 01-B-72B, 2002 WL 338294, at *12-13 (D. Colo. March 4, 2002) (victims of school shooting perpetrated by students who watched violent motion pictures and played violent video games had no strict liability claim against manufacturers and distributors of video games and motion pictures).

${ }_{173}$ One commentator has called for the creation of a "commercial intellect products liability" doctrine that would provide a remedy for the harm that befalls a cook, for example, when preparing a recipe from a cookbook that calls for the use of a poisonous root. See, Jonathan B. Mintz, Strict Liability for Commercial Intellect, 41 CATH U. L. Rev. 617 (1992) (discussing Cardozo v. True, 342 So.2d 1053 (Fla. Dist. Ct. App. 1977) (plaintiff failed to state a claim under UCC implied warranty theory of strict liability regarding recipe which called for use of root that was injured when she tested the raw root while preparing the dish)).

${ }^{174}$ Wilson, 198 F. Supp. 2d 167 at 13; Cf. Andrew B. Sims, Tort Liability for Physical Injuries Allegedly

Resulting From Media Speech: A Comprehensive First Amendment Approach, 34 ARIZ L. REv. 231 (1992) (dividing "media speech" tort cases into four categories: instruction, exhortation [which includes subliminal messages], inspiration and facilitation).

${ }^{175}$ See, e.g., Watters v. TSR Inc., 904 F.2d 378, 380-381 (6 ${ }^{\text {th }}$ Cir. 1990) (role-playing Dungeons and Dragons game not a product); Herceg, $565 \mathrm{~F}$. Supp. at 803 (inflammatory article on the practice of 'autoerotic asphyxiation'" not a product); James, 90 F. Supp. 2d at 811 ("intangible thoughts, ideas and messages contained within games, movies and website materials are not products for the purposes of strict products liability."); Sanders, 2002 WL 338294 at *11-13 ("thoughts, images, ideas, and messages contained in movies and video games" not products).

${ }^{176}$ Virtual worlds are Internet based and most of them do not require any hardware.
} 


\section{B. The Liability Waiver in the Terms of Service}

\section{(1) Contracts Aspect}

The court can refuse to enforce an unconscionable contract or clause or can restrict the applicability of a clause in a contract in order to prevent an unconscionable outcome. ${ }^{177}$ Since the law does not define unconscionability, the courts usually require the unconscionability to be both procedural and essential. ${ }^{178}$ The first part of the test, procedural unconscionability, examines the agreement for evidence of unequal bargaining power. ${ }^{179}$ End User License Agreements and virtual worlds' Terms Of Service usually meet the definition of procedural unconscionaility. ${ }^{180}$ The user has no bargaining power; the Terms Of Service are contracts binding millions of users who generally accept them without reading them. ${ }^{181}$ These kinds of contracts tend to indicate procedural unconscionability. ${ }^{182}$ Generally, these contracts arrive in the mass market in a finished format, giving the consumer no ability to negotiate. ${ }^{183}$ In addition, the contract language typically uses general terms and the contract reflects only the developer's interests. ${ }^{184}$ Therefore, the user's surprise about the inflexibility of the agreements provisions is also an element of procedural unconscionability in California. ${ }^{185}$

The second part, essential unconscionability, examines the contract for inflexible, one sided, or draconian conditions. ${ }^{186}$ Terms Of Service usually meet the definition of essential

\footnotetext{
${ }^{177}$ See, e.g., Cal. Com. Code \$2-302 (West 2010); Susan Randall, Judicial Attitudes Toward Arbitration and the Resurgence of Unconscionability, 52 BUFF. L. REV. 185, 190 (2004).

${ }^{178}$ Randall, supra note 177 at 185.

${ }^{179} I d$.

${ }^{180}$ Jason T. Kunze, Comment, Regulating Virtual Worlds Optimally: The Model End User License Agreement, 7 NW. J. TECH. \& INTELL. PROP. 102, *22 (2008).

${ }^{181}$ See generally, Alfred Fritzsche, Trespass to (Virtual) Chattels: Assessing Online Gamers' Authority to Sell In-Game Assets Where Adhesive Contracts Prohibit Such Activity, 8 U.C. DAVIS Bus. L.J. 235 (2007).

${ }^{182}$ Bragg v. Linden Research, Inc., 487 F. Supp. 2d 593, 606 (D. Pa. 2007) ("Although Bragg is an experienced attorney...he was never presented with an opportunity to use his experience and lawyering skills to negotiate terms different from the [EULA] that Linden offered"). See also id. at 605 ("A contract or clause is procedurally unconscionable if it is a contract of adhesion.").

${ }^{183} \mathrm{Id}$. at 606 .

${ }^{184} \mathrm{Id}$.

${ }^{185}$ Id. (quoting Gutierrez v. Autowest, Inc., 114 Cal. Rptr. 3d 267, 275 (Cal. Ct. App. 2003)).

${ }^{186}$ Randall, supra note 177 , at 185.
} 
unconscionability as well. ${ }^{187}$ Most of the Terms Of Service provide the developer with godlike, uncontrolled, one sided power, while the user has few or no rights at all. ${ }^{188}$ For example, even virtual worlds pretending to protect user's intellectual property ${ }^{189}$ reserve for the developer full control of currency, similar to a casino that arbitrarily eliminates the market for its chips, and saves all its customers money. ${ }^{190}$ Moreover, the Terms Of Service typically allow developers to change the terms at any given time without notice to the user. ${ }^{191}$

In Bragg v. Linden Lab, the District Court for the Eastern District of Pennsylvania held invalid a compelling arbitration provision in Second Life's Terms Of Service. ${ }^{192}$ The plaintiff, Bragg, filed suit in Pennsylvania and Linden Lab moved to dismiss on the grounds of absence of jurisdiction. ${ }^{193}$ The court found that Linden Lab's nationwide campaign was enough to maintain the minimum contacts required for personal jurisdiction in Pennsylvania and rejected Linden Lab's motion to dismiss. ${ }^{194}$ The court next addressed Linden Lab's demand that the court compel arbitration based on the Terms Of Service provision. ${ }^{195}$ The court found that this provision was meant to surprise the user, as it was "buried" in a long paragraph titled "General Provisions." 196 The court, therefore, held that the Terms Of Service

\footnotetext{
${ }^{187} I d$.

${ }^{188}$ Kunze, supra note 180 , at $* 17$.

${ }^{189}$ See, e.g., Press Release, Second Life Residents To Own Digital Creations (Nov. 14, 2003), available at http://creativecommons.org/press-releases/entry/3906 ("Unlike traditional online game environments where anything created in-world is owned by the service provider, Second Life has responded to its residents' desire to own their work just as they would any other original creations. Under these terms they can create, and sell derivative works based on content they've made, or license the work to others."). See also Steven J. Horowitz, Competing Lockean Claims to Virtual Property, 20 HARV. J. LAW \& TECH. 443, 448 (2007) ("Linden Lab's Second Life is supposed to be different. Second Life purports to protect the virtual and intellectual property rights of its users."); Ben Quarmby, Pirates Among the Second Life Islands - Why You Should Monitor the Misuse of your Intellectual Property in Online Virtual Worlds, 26 CARDOZO ARTS \& ENT. L.J. 667 (2008-2009). However, see Kathleen E. McCarthy, User Generated Content Affecting Trademarks, Including Real Trademarks in Virtual Worlds, 962 PLI/Pat 657, 719 (a filed Complaint alleges Linden Research activities that are not consistent with this press release).

${ }^{190}$ Kunze, supra note 180 , at $* 17$.

${ }^{191} \mathrm{Id}$.

192 Bragg, 487 F. Supp. 2d at 611.

${ }^{193}$ Defandant's Notice of Removal, Bragg, 487 F.Supp.2d 593 (Nov. 7, 2006), available at http://lawyers.com/Linden_Notice_Of_Removal_To_Federal_Court.pdf.

${ }^{194}$ Bragg, 487 F. Supp. $2 \mathrm{~d}$ at 611.

${ }^{195}$ Defendant's Motion to Compel Arbitration, Bragg, 487 F.Supp.2d 593 (Nov. 14, 2006), available at http://lawy-ers.com/linden_motion_to_compel_arbitration.pdf.

${ }^{196}$ Bragg, 487 F. Supp. 2d at 612.
} 
met the definition of procedural unconscionability. ${ }^{197}$ Essential unconscionability was found in some of the Terms Of Service provisions, including the lack of mutuality in forcing arbitration on the user, giving Linden Labs the choice of forum, and forcing the user to pay the high cost arbitration in San-Francisco as opposed to the lower cost of filing suit in Pennsylvania. ${ }^{198}$ The Bragg case most certainly deals with property, but it can be assumed that other courts will utilize similar reasoning in lawsuits brought before them seeking recovery for damages caused to the user, and that in the future, the court will need to examine the conscionability of the liability waiver in the virtual world's Terms Of Service.

\section{(2) Consumer Protection Aspect}

The Consumer Protection Act ${ }^{199}$ states that any waiver causing the consumer to give up its rights is opposed to public policy and therefore void and unenforceable. ${ }^{200}$ For example, in a class-action lawsuit brought by Internet subscribers against their Internet supplier, it was claimed that the supplier had breached the Consumer Protection Act by including in its service agreement a waiver stating that Virginia is the proper forum for litigation and applying Virginia law to the agreement. ${ }^{201}$ The court held that the plaintiffs' rights would be significantly harmed if they were required to litigate in Virginia where the remedies are very limited. ${ }^{202}$ It is therefore possible to assume that future courts will find the virtual world's developer's liability waiver void, as it forces the consumer to waive its rights.

\footnotetext{
${ }^{197}$ See Comb v. PayPal, Inc., 218 F. Supp. 2d 1165 (D. Cal. 2002) (class-action lawsuit by individuals challenging PayPal's arbitration provision, which was held unconscionable).

${ }^{198}$ Bragg, 487 F. Supp. 2d at 593.

${ }^{199}$ Cal. Civ. Code, $\S 1751$ (West 2010).

200 13A Cal. Jur. 3d Consumer and Borrower Protection Laws $§ 121$ (1972).

${ }^{201}$ America Online, Inc. v. Superior Court, 108 Cal. Rptr. 2d 699, 702 (Cal. Ct. App. 2001).

${ }^{202} I d$.
} 


\section{ISP and Constitutional Immunity}

\section{(1) Internet Service Providers Immunity}

An additional factor to consider when contemplating the legal regulation of virtual worlds is the immunity provided to Internet Service Providers by the Communication Decency Act. ${ }^{203}$ Legal regulation seeking to impose liability upon virtual worlds developers, must take this immunity into account. For this reason, I will review below the Communication Decency Act's "Good Samaritan" ruling and its relevant implications in virtual world regulation. A question might be raised as to whether similar immunity, as is offered to Internet Service Providers, should or will be offered to virtual worlds developers.

In Stratton Oakmont, Inc. v. Prodigy Servs. Co., the New York Supreme Court held a defendant liable for defamation for posts created by a third party on the defendant's server because the defendant had maintained control of the content on its servers. ${ }^{204}$ Internet companies and commenting scholars have claimed that this ruling exposes Internet Service Providers to unlimited liability. ${ }^{205}$ These critics claim that this ruling will lead Internet Service Providers to decline supervision of the content on their servers or will result in dramatic increases in Internet access prices. ${ }^{206}$ Congress later adopted this approach ${ }^{207}$ by enacting Clause 230 of the Communication Decency Act. ${ }^{208}$ Later, as was decided in Zeran v. $A O L,{ }^{209}$ the court's grant of strict immunity, stemming from Clause 230, was accepted widely in Federal and state courts. ${ }^{210}$ This immunity is applicable even in cases where the Internet

\footnotetext{
203 Telecommunications Act, Pub.L. 104-104, § 230, 110 Stat. 56 (1996).

2041995 WL 323710 (N.Y. Sup. Ct. May 24, 1995).

${ }^{205}$ Brian C. McManus, Rethinking Defamation Liability for Internet Service Providers, 35 SUFFOLK U.L. REV. 647,668 (2001).

${ }^{206} I d$.

${ }^{207}$ S. REP. No. 104-230, at 194 (1996); H.R. REP No. 104-458, at 194 (1996) (Conf. Rep.); 141 CONG. REC. H8469-H8470 (daily ed. Jun. 14, 1995).

${ }^{208}$ Telecommunications Act, Pub.L. 104-104, § 230.

${ }^{209} 129$ F. 3d 327, 330-31 (4th Cir. 1997) (Plaintiff sued defendant for defamation due to a posting by third party on its bulletin board which led to people sending him murder threats. Court found the defendant immune under $230 \S$ being merely an Internet Service Provider and not an Internet Content Provider).

${ }^{210}$ Ben Ezra, Weinstein, and Co., Inc. v. America Online, Inc., 206 F. 3d 980, 986 (10th Cir. 2000); Morrison v. America Online, Inc., 153 F. Supp. 2d 930, 933-34 (N.D. Ind. 2001); PatentWizard, Inc. v. Kinko’s, Inc., 163 F.
} 
Service Provider knew that the content constituted a wrong, ${ }^{211}$ whether it is a first publication or renewed publication, ${ }^{212}$ even when the content creator worked for the Internet Service Provider, ${ }^{213}$ even if the Internet Service Provider edited the content, ${ }^{214}$ and even if the content is in response to questions created by the Internet Service Provider. ${ }^{215}$

In Fair Housing Council of San Fernando Valley v. Roommates.com, LLC, the Ninth Circuit Court of Appeals issued a ruling contrary to common rulings on immunity. ${ }^{216}$ The court held that a website will be found liable for illegal content if it was partly or fully connected to the content development. ${ }^{217}$ In addition, the court held that a website will be liable for its search engine, if the search engine had built in illegal options. ${ }^{218}$ A website that encourages illegal content will, therefore, be exposed to liability and be deemed a content service provider. $^{219}$ In borderline cases, the court assumes a presumption of immunity. ${ }^{220}$ This holding means that Internet Service Providers' liability will be determined primarily by its level of involvement in the creation of the illegal content. ${ }^{221}$ A case similar to the type of cases that might be brought under legal regulation of virtual worlds is Doe v. MySpace. ${ }^{222}$

\footnotetext{
Supp. 2d 1069, 1071 (D. S.D. 2001); Green v. America Online, 318 F. 3d 465, 470-71 (3rd Cir. 2003); Doe One v. Oliver, 755 A. 2d 1000, 1003-04 (Conn. Super. Ct 2000); Doe v. America Online, Inc., 783 So.2d 1010, 1013-17 (Fla. 2001); Schneider v. Amazon.com, Inc., 31 P.3d 37, 40-42 (Wash, Ct, App. 2001); Barrett v. Fonorow, 799 N.E. 2d 916, 923-25 (Ill. App. Ct 2003); Donato v. Moldow, 865 A. 2d 711, 720-27 (N.J. Super. Ct. App. Div. 2005); Austin v. CrystalTech Web Hosting, 125 P. 3d 389, 392-94 (Ariz. Ct. App. 2005); Kathleen R. v. City of Livermore, 87, 684 (Cal. Ct. App. 4th 2001); Gentry v. eBay, Inc., 99, 816 (Cal. App. 4th 2002); Lunny v. Prodigy, S. 2d 557 (N.Y. 1998).

${ }^{211}$ Zeran v. America Online, Inc., 129 F.3d 327, 330-31 (4th Cir. 1997).

${ }^{212}$ Barrett v. Rosenthal, 146 P.3d 510 (Cal. 2006).

${ }^{213}$ Blumenthal v. Drudge, 992 F. Supp. 44, 61 (D. D.C. 1998).

${ }^{214}$ Batzel v. Smith, 333 F. 3d 1018, 1021 (9th Cir. 2003).

${ }^{215}$ Carafano v. Metrosplash.com, Inc., 339 F. 3d 1119, 1123-24 (9th Cir. 2003).

2162008 US App.LEXIS 7066 (9th Cir. 2008).

${ }^{217} \mathrm{Id}$. at 5722.

${ }^{218} \mathrm{Id}$.

${ }^{219} I d$.

${ }^{220} \mathrm{Id}$.

${ }^{221}$ While in Carafano, the site supplied the natural framework and the imposter is the one that misused it, and therefore, the site is not an ICP and is immune under $\S 230$; In Roommates.com the framework, as well as the search engine supplied by the website was not natural but encouraged illegal use, and therefore, the site was an ICP and is not immune under $\S 230$.

${ }^{222}$ Doe v. Myspace, 474 F. Supp. 2d 843 (W.D. Tex. 2007).
} 
Despite the fact that Myspace, with more than 10 million users under 18 years of age, ${ }^{223}$ was legally required to implement additional security measures to protect its minor users from sex predators, ${ }^{224}$ the District Court for the Western District of Texas held that Myspace was not liable for failing to prevent adult users from contacting and sexually attacking a minor user. ${ }^{225}$ Relying on Zaren, the court found Myspace immune. ${ }^{226}$ Nevertheless, the court then examined the negligence claim under a common law perspective and found that no special relationship was established that created duty in Myspace. ${ }^{227}$ Therefore, the court held that "[t]o impose a duty under these circumstances for MySpace (sic) to confirm or determine the age of each applicant, with liability resulting from negligence in performing or not performing that duty, would of course stop MySpace's (sic) business in its tracks and close this avenue of communication, which Congress in its wisdom has decided to protect." ${ }^{228}$ The court further commented that "If anyone had a duty to protect Julie Doe, it was her parents, not MySpace (sic)."229

Following the decision in Doe v. Myspace, Myspace implemented a wide variety of measures meant to protect minors using the site. ${ }^{230}$ These measures included hiring a head security officer, creating television and onsite ads warning children to beware of strangers on the Internet, and implementing parent control software and other measures restricting

\footnotetext{
${ }^{223}$ Julia Angwin \& Brian Steinberg, News Corp. Goal: Make MySpace Safer for Teens, WALL ST. J., Feb. 17, 2006 at B1.

${ }^{224}$ See, e.g., Elizabeth P. Stedman, Comment: MySpace, but Whose Responsibility? Liability of SocialNetworking Websites When Offline Sexual Assault of Minors Follows Online Interaction, 14 VILL. SPORTS \& ENT. L. J. 363 (2007); Rebecca Porter, Lawyers, Advocates Look to Protect Kids from Web Networking Dangers, 42 TRIAL 16 (Oct. 2006).

${ }^{225}$ Julia Doe (13) registered and opened an account at Myspace. Shortly after joining the site, Pit Solis (19) contacted Julia. The two met and Pit sexually attacked her. Julia's mother, Jane, filed a complaint against Myspace claiming the company was negligent in not implementing reasonable security measures to prevent dangerous adult users accessing the site to contact minors. After the case was transferred to federal court, Myspace claimed it should be dismissed under $\S 230$.

${ }^{226}$ Doe, 474 F. Supp. $2 \mathrm{~d}$ at 844.

${ }^{227} \mathrm{Id}$.

${ }^{228} \mathrm{Id}$.

${ }^{229} \mathrm{Id}$.

${ }^{230}$ Emma Henry, MySpace Agrees Child Protection Measures, TELEGRAPH (UK), Jan. 16, 2008, available at http://www.telegraph.co.uk/news/uknews/1575635/MySpace-agrees-child-protection-measures.html.
} 
interaction between minors and adults in the site. ${ }^{231}$ Recently Myspace announced that it plans to develop additional security measures. ${ }^{232}$

Another case relevant to the issue of virtual world regulation is Doe $v$. SexSearch.com. ${ }^{233}$ In October 2005, plaintiff, John Doe used the website to contact Jane Roe. $^{234}$ Jane Roe, a 14-year-old represented herself on the website as an 18 -year-old. ${ }^{235}$ On Nov. 15, 2005 John and Jane met in Jane's house and had consensual sexual relations. ${ }^{236}$ On Dec. 30, 2005, John was arrested and charged with engaging in unlawful sexual conduct with a minor. ${ }^{237}$ Following his arrest, John sued SexSearch.com claiming fourteen separate causes of action summing up to two main causes: a) the defendants' failure to discover that Jane lied about her age; and b) unconstitutional contract provisions. ${ }^{238}$ In granting the defendant's motion to dismiss under Federal Rules of Civil Procedure 12(b)(6), ${ }^{239}$ the district court found that section 230(c)(1) of the Communication Decency Act applied to SexSearch.com ${ }^{240}$ and provided immunity from liability for third party content - in this case, the misrepresentation of Jane Roe's age. ${ }^{241}$

It appears that the Good Samaritan clause and the manner in which the courts have interpreted it (except in Roommates.com) provide blanket immunity to virtual worlds against claims of liability. Even if a plaintiff can prove tort, contract, or some other form of liability of virtual worlds developers for damages caused or that might be caused to minors from using these worlds, he will still face Good Samaritan immunity. Only if the plaintiff can show ${ }^{231} I d$

${ }^{232}$ See Press Release, MySpace and Attorneys General Announce Joint Effort to Promote Industry-Wide Internet Safety Principles (Jan. 16, 2008), available at http://www.newscorp.com/news/news 363.html. 2008.

${ }^{233}$ Doe v. SexSearch.com, 502 F. Supp. 2d 719 (N.D. Ohio 2007).

${ }^{234} \mathrm{Id}$. at 722 .

${ }^{235} I d$.

${ }^{236} I d$.

${ }^{237} I d$.

${ }^{238} I d$. at $723-4$.

${ }^{239}$ Fed. R. Civ. P. 12(b)(6) ("failure to state a claim upon which relief can be granted").

${ }^{240}$ SexSearch.com, 502 F. Supp. 2d at 728, 724 (The court on page 724 laid out the test to determine the applicability of the CDA: "(1) SexSearch is a "provider of an interactive computer service'; (2) the claim is based on "information provided by another information content provider'; and (3) the claim would treat SexSearch "as publisher or speaker' of that information.").

${ }^{241}$ Id. at 728 . 
that the virtual worlds developers are the ones creating the addictive content while they knew or should have known that the content causes addiction and/or dangerously blurs borders. In considering regulation of virtual worlds we should therefore distinguish between Second Life, for example, in which the virtual world is created by users and might therefore receive immunity under the Good Samaritan clause, and MMORPG's, in which the developers create the world's plot and the virtual world's content.

\section{(2) Constitutional Immunity}

Assuming that the current law in California does not protect minors from the dangers of virtual worlds use, a question arises as to whether there is a constitutional limitation that might prevent legislation on virtual worlds issues. In light of the fact that virtual worlds are new information technology, no current legislation or court precedence offers insight into its regulation. Nevertheless, analogies can be drawn between regulating use by minors of violent video games to virtual worlds issues. ${ }^{242}$ It should be mentioned that the analogy between video games and virtual worlds is partial and not free of doubt. On one hand, the freedom of speech argument is valid. On the other hand, while the need to regulate minor's use of video games stems from their violent nature, not all virtual worlds involve violence. ${ }^{243}$

In the United States, legal restrictions limiting children's usage of violent video games were widely examined during the developing of laws creating such limitations. ${ }^{244}$ Relying on the same principles that paved the way for constitutional regulation of obscenity, ${ }^{245}$ legislators introduced a great deal of research establishing the connection between violent entertainment and aggressive behavior among children, in order to justify these

\footnotetext{
${ }^{242}$ See Marc Jonathan Blitz, A First Amendment for Second Life: What Virtual Worlds Mean for the Law of Video Games, 11 VAND. J. ENT. \& TECH. L. 779 (2009).

${ }^{243}$ See, e.g., Kent, supra note 15; Lauren Gonzales, When Two Tribes Go to War: A History of Video Game Controversy: The Major Offenders, GAMESPOT, http:/www.gamespot.com/features/6090892/ (last visited October 27, 2010).

${ }^{244}$ See, e.g., Cal. Civ. Code $\$ \$ 1746-1746.5$ (West 2010).

${ }^{245}$ See Video Software Dealers Ass'n v. Schwarzenegger, 401 F. Supp. 2d 1034, 1045 (N.D. Cal. 2005).
} 
restrictions. ${ }^{246}$ Despite the fact that ordinances restricting minors use of violent video games were formulated using a narrow definition of violence and restricting the hiring of minors and selling of violent video games to minors under 17 years old, efforts to defend this type of legislation were frustrated by the court. ${ }^{247}$ Three critical arguments have led courts to determine that such restrictions are unconstitutional: 1) protection of free speech is afforded by the First Amendment of the United States Constitution; 2) violent images are not, in legal terms, obscenity; and 3) the social science evidence is not convincing and most of it is speculative. ${ }^{248}$ In the last few years not even one ordinance restricting minors use of violent video games has survived judicial criticism. ${ }^{249}$

It is clear that restricting adults' expression carries the potential of serious damage to the right of free speech and expression. That risk, however, is much smaller when dealing with minors. Nevertheless, it is important to identify that when children reach the age of 18 , their right to free speech becomes more important. At 18 years of age they earn the right to vote and need to learn the rules of participation, by receiving information as well as adding their new voices to the public debate. ${ }^{250}$

In light of the rejection of attempts to legally regulate use of violent video games by minors, scholars have argued that legislators should stop comparing video game violence with obscenity, and instead begin claiming that in special circumstances, the Constitution

\footnotetext{
${ }^{246} I d$.

${ }^{247}$ Amusement Mach. Ass'n v. Kendrick, 244 F. 3d 572, 580 (7th Cir. 2001).

${ }^{248} I d$.

${ }^{249}$ See, e.g., Entm't Merchs. Ass'n v. Henry, U.S. Dist. LEXIS 74186 (W.D. Okla. 2006); Enterntainment Software Association v. Foti, 451 F. Supp. 2d 823, 837 (M.D. La. 2006); Entm’t Software Ass'n v. Hatch, 443 F. Supp. 2d 1065, 1073 (D. Minn. 2006); Entm't Software Ass'n v. Granholm, 426 F. Supp. 2d 646, 656 (E.D. Mich. 2006); Video Software Dealers Ass'n v. Schwarzenegger, 401 F. Supp. 2d 1034, 1048 (N.D. Cal. 2005); Entm't Software Ass'n v. Blagojevich, 404 F. Supp. 2d 1051, 1083 (N.D. Ill. 2005); Video Software Dealers Ass'n v. Maleng, 325 F. Supp. 2D 1180, 1191 (W.D. Wash. 2004).

${ }^{250}$ Kevin W. Saunders, Children and the First Amendment Symposium: The Cost of Errors in the Debate Over Media Harm to Children, 2005 Mich ST. L. REV. 771, 786 (2005).
} 
allows reasonable restriction of distribution of offending material to minors when the influence on the freedom of expression among adults is minimal. ${ }^{251}$

Two central factors contribute to the courts' rejection of legislation regulating minors' use of video games: the uncertainty about whether video game violence can lead to violence in the real world and the First Amendment freedom of expression. ${ }^{252}$ It can be assumed that these two factors will also be considered when legislation regulating minors' use of virtual worlds is examined. In this case, it is still difficult to determine, based on the limited existing research regarding the possible damage to minors from the use of virtual worlds, if there is better evidence than exists with regards to video games violence.

Nevertheless, in light of the findings set forth in this article, should there be an attempt to enact legislation regulating the use of virtual worlds by minors, it would be erroneous of the courts to completely rely on the video games precedence. Rather, courts should balance the dangers posed to minors using this innovative information technology, with the First Amendment protection, which is less protective when involving minors. In summary, two powerful obstacles stand in the way of legally regulating the use of virtual worlds by minors: freedom of speech and the Good Samaritan Act. These obstacles, as described completely above, as well as past experience with attempts to legally regulate video games, seem to suggest an almost absolute bar to any attempt to legally regulate virtual worlds minors use in the United States.

\section{Parents Liability}

Aside from legal regulation and self-regulation of minors' use of virtual worlds, one cannot ignore the parents' responsibility to monitor this use and, therefore, the liability of

\footnotetext{
${ }^{251}$ Christopher Dean, Returning the Pig to Its Pen: A Pragmatic Approach to Regulating Minors' Access to Violent Video Games, 75 GEO. WASH. L. REV. 136, 137 (2006).

${ }^{252} I d$.
} 
parents for damages that can be caused by minors using virtual worlds. ${ }^{253}$ Accordingly, a question arises as to whether it is possible to force legal liability on parents, or whether the existence of parents' liability diminishes the ability to hold virtual worlds developers liable, and indirectly, the duty of the state to regulate the use.

An article addressing parental liability for illegal Internet file downloading by their children sets forth two claims relevant to this issue. ${ }^{254}$ The first is negligence for the delivery of a dangerous instrument to a child. ${ }^{255}$ In the common law, a parent could be found negligent if he gave a child or allowed him to access to a dangerous instrument, like a gun. ${ }^{256}$ A parent could be found negligent if he supplied his child with a dangerous object such as matches or a vehicle because of the child's immaturity or his tendency to use it incorrectly or in a dangerous manner. ${ }^{257}$ The dangerous instrument doctrine is based on the idea that one should expect that providing a child access to a dangerous object will result in injury. While a computer is not generally considered an instrument capable of harming the body or property of the user or a third party, it shares some of the potentially dangerous characteristics of other dangerous instruments.

The second wrong addressed in the aforementioned article concerns parental supervision of the child. ${ }^{258}$ In the common law, a parent could be held liable if he knew his child had the tendency to commit intentional wrongs, and in spite of that, did not take any reasonable steps to protect others from the damages of such wrongdoing. ${ }^{259}$ This refers to

\footnotetext{
${ }^{253}$ Joshua Fairfield, Virtual Parentalism, 66 WASH. \& LEE L. REV. 1215 (2009).

${ }^{254}$ Janelle A. Weber, Note: Don't Drink, Don't Smoke, Don't Download: Parents' Liability for Their Children's File Sharing, 57 FLA. L. REV. 1163 (2005).

${ }^{255} \mathrm{Id}$.

${ }^{256}$ Prosser AND KeEton On THe LaW OF TORTS 914 (W. Page Keeton et al. eds., 5th ed. 1984).

${ }^{257} I d$.

${ }^{258}$ Weber, supra note 254 , at 1165 .

${ }^{259}$ See, e.g., Wade R. Habeeb, Annotation, Parents' Liability for Injury or Damage Intentionally Inflicted by Minor Child, 54 A.L.R. 3d 974 (2010) (collecting cases in which plaintiffs sued parents for their children's intentional torts or the parents' own negligent supervision of their children); The Restatement of Torts describes this tort in the following manner: "A parent is under a duty to exercise reasonable care so to control his minor child as to prevent it from intentionally harming others or from so conducting itself as to create an unreasonable risk of bodily harm to them, if the parent (a) knows or has reason to know that he has the ability to control his
} 
parental liability to a third party who is injured by the child's actions and therefore could provide possible grounds for parental liability in the discussed context, where the child himself is injured.

According to the criminal code, a person who has a child in his custody or care is a felon if that person deliberately causes or allows the child's health or body to be hurt, or causes or allows the child to be placed in a situation where danger of such harm exists. ${ }^{260}$ If a reasonable person knew or should have known that the circumstances could cause serious bodily harm or death, then the punishment is imprisonment. ${ }^{261}$ This law requires proof of criminal negligence, requiring recklessness or a deviation from the accepted standard of care. It has been recognized that parents often make mistakes that may harm children's health or cause them injury, but these parents will not be accused nor convicted of cruelty to their child unless they were criminally negligent. ${ }^{262}$ In addition, a parent who does not supervise his child properly is not considered in breach of his legal duty, and therefore, the torts arrangement does not apply to him. ${ }^{263}$

In search of a redeeming formula to determine when parents should be held liable, United States courts tried to delineate levels of severity in acts of negligence. ${ }^{264}$

child, and (b) knows or should know of the necessity and opportunity for exercising such control." RESTATEMENT (SECOND) OF TORTS $\S 316$ (1965).

${ }^{260}$ See e.g., 32 CAL. Jur. 3D. FAmily LaW $§ 300$ (1972); Cal. Penal Code $\S 273 \mathrm{a}$ (b) (West 2010).

${ }^{261}$ CAL. PenAl CODE $§ 273 a(a)$ (West 2010).

${ }^{262}$ See, e.g., People v. Deskin, 13 Cal. Rptr. 2d 391 (Cal. Ct. App. 1992); In re Matthew S., 49 Cal. Rptr. 2d 139 (Cal.Ct. App. 1996); Jennifer M. Collins, Crime and Parenthood: The Uneasy Case for Prosecuting Negligent Parents, 100 NW. U. L. REV. 807 (2006).

${ }^{263}$ Holodook v. Spencer, 324 N.E. 2d 338 (N.Y. 1974) ("A parent's misjudgment in supervising his child does not amount to the breach of a legal duty and therefore is not a tort.").

${ }^{264}$ See e.g., E. Sylvester, Denying the Existence of a Legal Duty Between a Mother and her Unborn Child, 33 AKRon L. ReV. 107 (1999); J.J. Basgier, Children's Rights: A Renewed Call for the End of Parental Immunity in Alabama and Arguments for the Further of a Child's Right to Sue, 26 LAW \& PsYCHOL. REV. 123 (2002); S.L. Haley, The Parental Tort Immunity Doctrine: Is it Defensible Defense?, 30 U. RICH. L. REV. 575 (1996). 


\section{The LAW IN China}

An example of laws regulating the virtual worlds use by minors is found in China, which has no First Amendment or Good Samaritan limitations. In 2005, the Chinese government introduced the "Online Game Anti-Fatigue System." 265 The following year, the system was changed to limit application to users under the age of $18 .{ }^{266}$ However, reports indicate that minors in China have found and continue to find ways to bypass these restrictions. $^{267}$

On April 14, 2007 the Chinese government enacted "anti addiction" regulations requiring that anti addiction software be installed in virtual worlds to limit online use by those under the age of $18 .{ }^{268}$ Virtual worlds failing to install this software by July 16, 2007 were required to be shut down. ${ }^{269}$ The software is designed to measure the amount of time the minor uses the virtual world, designating up to 3 hours as healthy use, 3-5 hours as "fatigue," and more than 5 hours as unhealthy. ${ }^{270}$ The software is designed to measure the amount of time for which the minor uses the virtual world and the time for which he is away from the virtual world. An announcement appears when the length of use reaches one hour. ${ }^{271}$ When the length of use reaches 3 hours, an announcement appears indicating the time used and

\footnotetext{
${ }^{265}$ See, e.g., Dickie Mure, China Moves to Zap Online Game Addiction, FT.com (August 23, 2005), http://www.ft.com/cms/s/2/89ea206a-13f3-11da-af53-00000e2511c8.html (last visited October 27, 2010); China Market Intelligence Center, GAPP Regulates MMOs, Announces Fatigue System, CCIDReport.com (June 19, 2006), http://www.ccidreport.com/market/article/content/3376/200606/130937.html (last visited October 27, 2010).

${ }^{266}$ Brendan Sinclair, China's Online Game Regulations Relaxed, Gamespot.com (Jan. 16 2006), http://www.gamespot.com/pc/rpg/worldofwarcraft/news.html?sid=6142777- (last visited October 27, 2010).

${ }^{267}$ See, e.g., Zhou Zhengqian, Industry Unfazed, Gamers Unconvinced About Fatigue System, Pacific Epoch.com (Apr. 10, 2007), http://www.pacificepoch.com/newsstories?id=94553 0550 M (last visited October 27, 2010); Matt Peckham, Anti Online Game Addiction System ...Failing?, PCWorld.com (Apr. 10, 2007), http://blogs.pcworld.com/gameon/archives/004058.html (last visited October 27, 2010).

${ }^{268}$ Casey Lynch, China Declares War on Gaming Addiction, MonstersandCritics.com (Apr. 12, 2007), http://www.monstersandcritics.com/gaming/pc/features/article_1290338.php/China_declares_war_on_gaming addiction (last visited October 27, 2010).

${ }^{269} I d$.

${ }^{270}$ See China - Anti Fatigue System Regulation Translated, Playnoevil.com (Aug. 20, 2007), http://www.playnoevil.com/serendipity/index.php?/archives/1510-China-Anti-Fatigue-System-RegulationTranslated.html (last visited October 27, 2010).

${ }^{271} I d$.
} 
demanding that the user terminate the session. ${ }^{272}$ After more than 3 hours of use, an announcement appears stating that the user has entered the fatigue period and, as a result, can only earn half of any profit possible in the virtual world (profit meaning any advance in the level of the user Avatar including honor, reputation and any similar property). ${ }^{273}$ When use reaches more than 5 hours, a warning appears stating that the user has entered the unhealthy period and will no longer gain any profit in the virtual world. ${ }^{274}$ Normal use can only be regained after spending 5 hours outside of the virtual world. ${ }^{275}$ This final message will appear on the computer screen every 15 minutes. ${ }^{276}$

In addition, the second phase of China's new system requires the users to register using their real name and ID in order to prove their age when they register to use virtual worlds ("Real Identity Authentication"). ${ }^{277}$ The head office for news publications (GAPP) of the Chinese government demanded that virtual worlds companies complete the identity system assimilation in the first quarter of $2009 .^{278}$ The NASDAQ-traded virtual worlds company NetEase already announced the incorporation of the system into all the virtual worlds it operates. $^{279}$

Prior to this legislation, a suit was filed against Blizzard, the operator of the virtual world World of Warcraft, following the suicide of Zhang Xiaoyi, a brilliant 13-year-old high school student who jumped to his death on December 27, 2004, from the 24th floor of the building where he lived with his parents. Xiaoyi had played "Warcraft: Orcs and Humans" for 36 continuous hours and had left behind a letter explaining why he jumped: in order to

\footnotetext{
${ }^{272} I d$.

${ }^{273}$ Id.

274 Id.

$275 \mathrm{Id}$.

${ }^{276} \mathrm{Id}$.

${ }^{277}$ Noted: China to Fully Deploy Real Identity for Players in Online Games by End of March, Playnoevil.com (Feb. 23, 2009), http://playnoevil.com/serendipity/index.php?/archives/2415-NOTED-China-to-fully-deployReal-Identity-for-Players-in-Online-Games-by-end-of-March.html (last visited October 27, 2010).

${ }^{278} I d$.

${ }^{279} \mathrm{Id}$.
} 
join the heroes he admired from the game. ${ }^{280}$ Almost a year after Xiaoyi's suicide, a scholar who had researched Internet addiction named Zhang Chunliang was authorized by Xiaoyi's parents to sue Blizzard Entertainment. ${ }^{281}$ Chunliang claimed he was inspired to sue by the lawsuits filed against the American tobacco industry. The suit was filed in the Chaoyang People's District Court in Beijing. ${ }^{282}$

According to advocate Li Gang, who handled the Blizzard case, virtual worlds are rated with the "T" rating in the United States, meaning they are not suitable for children under 13 years old. However, when the virtual world is sold in China, there is no age limit for using it. The deceased was 11 years old when he began using the virtual world, and he was 13 years old when he jumped to his death. Therefore the lawsuit suggested the following demand:

In the product package, in the user instruction guide and in the game itself, the level of violence should be indicated; there should be a warning regarding the influence of intensive use that can lead to addiction and bad health; there should be taken technical steps to prevent addiction; a sum of 100,000 RMB $(\$ 12,500)$ is demanded as recovery for the victim's death. ${ }^{283}$

Access to data regarding China's virtual worlds regulations is restricted by the Chinese government; however, reports indicate problems with the system, such as the purchase of an identity for $\$ 1$, lack of coordination between virtual worlds operators, and between virtual worlds of the same operator, enabling minor users to use virtual worlds as long as they please without any sanctions while moving from one virtual world to another, and the ability to purchase adult identities for unlimited time use. ${ }^{284}$

\footnotetext{
${ }^{280}$ Tan Wei, Hooked on the Net, BEIJING REVIEw, available at http://www.bjreview.cn/EN/En-2005/05-46e/china-4.htm.

${ }^{281}$ Ying, supra note 61.

${ }^{282}$ Parents Seek Compensation From Online Game Seller for Suicide of Addicted Son, People's DAILY (China) (May 12, 2006), http://English.peopledaily.com.cn/200605/12/eng20060512 264879.html (last visited October 27, 2010).

${ }^{283}$ Ying, supra note 61.

${ }^{284}$ Games Fatigue System Proven to Be Volatile after First Week of Launch, RedLinechina.com (Jul. 23, 2007), http://www.redlinechina.com/main/?q=node/275 (last visited October 27, 2010).
} 


\section{REGULATION OF USE}

\section{BACKGROUND}

The suggestion of legal regulation of virtual worlds has been met with both objection and support. Despite opposition, several solutions have been proposed for regulating virtual worlds. This section addresses the reasons for objection to legal regulation and examines various models that have been proposed for regulating virtual worlds.

\section{A. Objection to Legal Regulation}

Many users do not want the law to interfere with virtual worlds at all because they are wary of radical legislation based on unproven claims that all video games are dangerous. ${ }^{285}$ This stance against regulation has support in scholarly research ${ }^{286}$ and is an expansion of arguments about the Internet made by cyberspace separatists in the $1990 \mathrm{~s} .{ }^{287}$ Critics have also argued that the courts and the legislature should give virtual communities the freedom to develop legal solutions and social norms to deal with inappropriate behavior. ${ }^{288}$ The demand for self-regulation is based on the argument that there is a need to protect the freedom and creativity of people designing virtual worlds and those using them, as part of their basic freedom. ${ }^{289}$ According to critics making this argument, state intervention will necessarily restrict the creativity of designers and users. ${ }^{290}$

\footnotetext{
${ }^{285}$ Joshua A.T. Fairfield, Anti-Social Contracts: The Contractual Governance of Virtual Worlds, 53 MCGiLL L. J. 427 (2008), available at http://lawjournal.mcgill.ca/documents/Fairfield.pdf.

${ }^{286}$ Timothy Wu, Application-Centered Internet Analysis, 84 VA. L. R. 1163, 1199-20 (1999) (arguing that state regulation of the Internet is unnecessary and redundant when the specific Internet environment is already selfregulated by a "private contractual order," and that, "the really 'pure' examples of this are the popular online games like Ultima Online or network Quake, which are multi-user versions of computer video games.").

${ }^{287}$ John Perry Barlow, A Declaration of the Independence of Cyberspace, Memex.org (Feb. 9, 1996), http://memex.org/barlow.html (last visited October 27, 2010) ("Governments of the Industrial World, you weary giants of flesh and steel, I come from Cyberspace, the new home of Mind. On behalf of the future, I ask you of the past to leave us alone.").

${ }^{288}$ See, e.g., Jack M. Balkin, Law and Liberty in Virtual Worlds, 49 N.Y.U. L. ReV. 63 (2004); James Grimmelmann, Virtual Borders: The Interdependence of Real and Virtual Worlds (N.Y.L. ScH. Legal Studies Research Paper No. 08/09-9, 2005), available at http://ssrn.com/abstract=868824.

${ }^{289} I d$.

${ }^{290} I d$.
} 
An additional argument about the unique character of virtual worlds is based on the freedom these worlds give users from the real world social norms forcing repetitive behavior. $^{291}$ Therefore, critics have argued that in light of the variety of interpersonal activities in the virtual world, virtual worlds governance is a very complicated question better left for internal forces, including market driven forces, to sort out, because the government cannot be trusted to properly understand how it should act and the consequences of different regulations. ${ }^{292}$ As was argued by Richard Bartle, one of MUD1 designers, "[M]y only concern here is that laws may be drawn up prematurely, without proper consultation with those who "get" virtual worlds, and we could be stuck with something unsuitable or unworkable as a consequence." 293 Judge Loretta A. Preska also offered insight on this point, saying, "The Internet may well be the premier technological innovation of the present age. Judges and legislators faced with adapting existing legal standards to the novel environment of cyberspace struggle with terms and concepts that the average American five-year-old tosses about with breezy familiarity." 294

\section{B. Support for Legal Regulation}

Conversely, it is argued that because virtual worlds are rapidly becoming part of people's lives and because they will probably serve more and more purposes in the future, legal regulation of virtual worlds is inevitable. ${ }^{295}$ Supporters have also suggested that virtual worlds can be utilized in order to examine laws applicable to the real world. ${ }^{296}$ As virtual worlds like Second Life are maturing both technologically and socially, supervision by legislators may become necessary. Despite courts' hesitation with deeming new technology

\footnotetext{
${ }^{291}$ See, e.g., Lastowka \& Hunter, supra note 13; Gregory F. Lastwoka \& Dan Hunter, Virtual Crimes, 49(1) N.Y.L. SCH. L. REV. 293 (2004), available at http://www.nyls.edu/user_files/1/3/4/17/49/v49n1p293-316.pdf. ${ }^{292} I d$.

${ }^{293}$ Richard BARTLE, Designing VirTUAL Worlds 621 (2004).

${ }^{294}$ Am. Libraries Ass'n v. Pataki, 969 F.Supp. 160, 161 (S.D.N.Y. 1997).

${ }^{295}$ Balkin, supra note 288 , at 75.

${ }^{296}$ Caroline M. Bradley_\& Michael A. Froomkin, Virtual Worlds, Real Rules, 49 N.Y.L. SCH. REV. 103 (2004).
} 
mediums as legitimate spaces in which real damage can occur, the law must be able to protect those who become addicted to and develop a dependency on their virtual world existences. ${ }^{297}$ The intervention of real world politics and law into the virtual space is, and should be, inevitable. ${ }^{298}$ As an emerging technology, virtual worlds are today what VCR's were in the 1980s or what the Internet was in 1993, and politicians and legislators in the United States have already observed this unique trend. ${ }^{299}$

For example, Congress penetrated the virtual wall between Second Life and the real world by designing a virtual United States Capital within the virtual world of Second Life. ${ }^{300}$ Congressman George Miller of California, Chairman of the Democratic Policy Committee, encouraged Members of Congress to participate in this virtual political forum. ${ }^{301}$ Therefore, if legislators can have a presence in the virtual world, so can the law. The Congressional Joint Economic Committee has even remarked that the virtual economic development preceded the law. ${ }^{302}$ This Committee suggested exploring the Second Life economy in order to better determine how to impose taxes on virtual income. ${ }^{303}$ The Committee further intends to examine some of the philosophical problems raised by people and corporations executing valuable business in the virtual realm. ${ }^{304}$ In the same way that the virtual wall is penetrable for taxation, it can be penetrated to protect the consumer, especially the minor consumer.

\footnotetext{
${ }^{297}$ Bettina Chin, Regulating Your Second Life, Defamition in Virtual Worlds, 72 BROOKLYN L. REV. 1303 (2007). 
However, it should be taken into consideration that virtual spaces are not identical and they can be used for many purposes besides commerce, including education, therapy, political association and artistic expression. ${ }^{305}$ Courts and the legislature must pay attention to these differences and avoid "one-size-fits-all" solutions. In this way, courts and the legislature will help preserve the right to design and use virtual worlds and assure plenty of available spaces for new forms of creativity, expression, and experimentation. ${ }^{306}$

In summary, no one is seriously claiming that there is no application of the law in virtual worlds. Beyond the existing application of the law in virtual worlds, there is no reason to have reservations about an increase in the law and legislative presence in the virtual worlds. If we are dealing with real damages, no immunity should be granted to those who cause the damages, solely because they were caused in the virtual realm. In addition, the determination that the legislature knows nothing about virtual worlds may have been true in the past, but it is clear that this is not true anymore. No one will seriously argue that copyright laws should not be applicable in virtual worlds. Circumstantial evidence indicates that the legislature is already present and active in virtual worlds.

\section{Regulation Models}

The main models for regulating virtual worlds are:

a. Command \& Control - The legislature requires virtual worlds' developers to take specific measures that the legislature believes will prevent or minimize harm to minors. ${ }^{307}$ An example of such regulation could be forcing virtual worlds' developers to develop and implement technology that restricts long periods of use by minors, or at least that would

\footnotetext{
${ }^{305}$ Balkin, supra note 288 , at 73 . 306 Id.

${ }^{307}$ See, e.g., Richard B. Stewart, Crisis in Tort Law? The Institutional Perspective, 54 U. CHI. L. Rev. 184 (1987); Bruce A. Ackerman \& Richard B. Stewart, Reforming Environmental Law, 37 StAN. L. ReV. 1333 (1985).
} 
require "adult consent" to continue use. A less obtrusive option could be to require developers to gather information regarding the possible danger to minors from the use of virtual worlds and then to publish this information.

b. Taxation \& Subsidies - The legislature regulates the use by taxing or subsidizing minors use of virtual worlds. The legislature could, for example, tax the use of virtual worlds that fail to take measures to prevent harm or, conversely, subsidize the use of "minor-friendly" virtual worlds. The government could establish a committee or other group with the authority to recommend taxation criteria, taxation levels, and what will be done with the taxes collected. In the same manner, the committee or other group would recommend criteria regarding subsidies. Money from this taxation will finance the committee's operations and will be used to treat addiction damages by, for example, establishing rehabilitation from virtual worlds' addiction institutions, conducting research on addiction issues, and raising societal awareness of the damages of virtual worlds use and the ways to prevent these damages. Subsidies will reduce the cost of using "minor friendly" virtual worlds and will assist in developing technology that will prevent harm to minors.

c. Participation - According to this model, while employing other methods of regulation, the legislature should allow, and even demand, participation of child-care activists and consumer-protection advocates in the decision-making process of virtual worlds companies. $^{308}$ In the same way, the legislature should demand participation by the public. Therefore it is recommended that a parent's representative should be a member of every virtual world company's Board of Directors in order to help prevent damage to minors caused by the use of virtual worlds. Moreover, it is recommended that every company operating a

\footnotetext{
${ }^{308}$ Orly Lobel, Interlocking Regulatory and Industrial Relations: The Governance of Workplace Safety, 57
} ADMIN. L. REV. 1071, 1104-15 (2005). 
virtual world should employ a manager responsible for minimizing damages to minor users in these worlds.

d. Litigation - The basis of this model is to increase the civil liability of corporations and use private enforcement procedures to force the corporations to work to prevent the damages caused by their actions. In this context, the legislature should impose liability on virtual worlds companies and then allow private and class action lawsuits based on tort, consumerprotection or products liability law. ${ }^{309}$ An additional possibility, although radical, is to impose criminal liability on virtual worlds companies and their directors, in extreme cases in which minors suffer bodily harm.

e. Management Regulation - The legislature should require virtual worlds companies to prepare a plan of action to prevent damage to minors, to publish it publicly and to implement it. ${ }^{310}$ One possibility is implementing a virtual worlds companies self-rating mechanism that will force each company to take measures to reduce damages in order to raise their rating. To ensure compliance, a licensing policy can be created that will allow operation and license admission only to those companies that effectively self-regulate.

f. Licensing Regulation - The legislature should enact rules regulating virtual worlds' activities by giving operation licenses only to companies that fulfill the terms set by the legislature aimed at creating safe use for minors. A virtual world without a valid license would be exposed to lawsuits and its activity could be blocked. Licensing would provide

\footnotetext{
${ }^{309}$ Stephen Sugerman, Performance-Based Regulation: Enterprise Responsibility for Reducing Death, Injury and Disease Caused by Consumer Products, 34 J. OF HEALTH POL'Y LAW 1035 (2009), available at http://jhppl.dukejournals.org/cgi/content/abstract/34/6/1035.

310 See, e.g., Robert A, Kagan, Adversarial Legalism: The American Way of Law (2001); Cary Coglianese \& David Lazer, Management-Based Regulation: Prescribing Private Management to Achieve Public Goals, 37 LAW \& SOC'Y REV. 691 (2003).
} 
minors and their parents with information regarding the choices available to them for safe use of virtual worlds.

g. Performance Based Regulation - For companies whose activity, even if also beneficial, is causing damages, a goal should be set to minimize the damages arising from their activity, and they should be held responsible for developing the best method to achieve this goal. ${ }^{311}$ In the context of virtual worlds, a goal of reducing the number of minors diagnosed as addicted to virtual worlds' use would be set, for example, and if virtual worlds companies do not meet this goal, a fine will be imposed.

\section{Advisable Solutions}

\section{A. The Property Aspect}

Various solutions for legal regulation of virtual worlds in disciplinary realm of property have been proposed. This section analyzes the various property-based solutions that have been proposed.

\section{(1) A Two-Tier Regulation - Internal \& External}

According to this proposal, virtual worlds should be governed by a two-tier system. First, everything occurring entirely within the virtual realm should be regulated by the virtual world's Terms Of Service. Second, transactions occurring outside a virtual world (meaning, in the real world) but involving goods or services within a virtual world, should be treated no differently from similar transactions in real-world goods or services. ${ }^{312}$ This system would create a separation between purely virtual matters and matters that overlap with the real world. Therefore, where there is overlap between the real world and virtual world, regulation

\footnotetext{
${ }^{311}$ Sugerman, supra note 309, at 1037.

${ }^{312}$ Rogers, supra note 12 , at 410.
} 
will be done using the existing laws from the real world, and yet matters unique to and solely occurring within the virtual world will be regulated using the Terms Of Service which create the normative frame of proceeding within that world.

The result of operating such a system in relation to the damages to minors claimed in this article is that once the implications of virtual worlds' use find expression in the real world, then the means of regulation will expand beyond the framework of the Terms Of Service and will incur the consequences of real-world laws. The advantage of this proposed solution is that it supports imposing liability for damages on virtual worlds companies as soon as the implication of virtual worlds' use cross the virtual border into the real world. The disadvantage is that such a solution may be applied post-ante, and besides deterrence, it does not prevent the damages ex-ante. It should also be noted that, at least in the tort law context, this is the actual legal situation today, absent the possible immunity for virtual worlds companies, reviewed in detail above.

\section{(2) Regulation by Choice}

Another proposal is that governments offer virtual worlds companies a variety of legal regimes to choose from, just as businesses can choose under which jurisdiction to

incorporate. ${ }^{313}$ For example, virtual worlds companies might be offered a spectrum of legal regimes to choose from; at one end of the spectrum we find "soft" regulation imposing no restrictions on minors use but increasing liability on virtual worlds companies, and on the other end, we find regulation imposing strong restrictions on minors use but providing immunity to virtual worlds companies from liability for any damage that might be caused to the users as a result of using these worlds. This freedom of choice will allow virtual worlds

${ }^{313}$ Balkin, supra note 288 , at 77. 
companies to choose the regime applicable to their world and will allow the user to choose his virtual world considering the legal regime governing it.

This approach has both advantages and disadvantages. The advantage of this proposed solution is the freedom of choice it would allow users and developers alike and the fact that it will create diverse regulation regimes allowing for comparison between them. An additional advantage is that this solution will allow personal adjustment to the wishes and conditions of every user in a way that can, for example, create the ability to steer high-risk user groups to virtual worlds in which the regulation is severe. The main disadvantage of this proposed solution is that, although it might be ideal for adult users, this article claims that it is undesirable to allow minors to use virtual worlds in which there is no regulation and/or that their developers bear no liability for damages that might be caused.

\section{(3) Self-Regulation}

Another proposed solution is that the responsibility to regulate should be imposed on virtual worlds companies. Specifically, virtual worlds companies would be responsible for determining the virtual world regulation policy, and the law outside the virtual world will impose on them strict liability for any damage that might occur to minor users through use of their virtual world. The primary justification for this solution is the fact that the companies that develop, build, and maintain the virtual worlds control the interaction in the virtual community. Therefore it has been argued that through code and contracts, virtual worlds companies hold the physical and legal abilities to enforce laws in the virtual worlds. ${ }^{314}$ Since virtual worlds companies control the proceedings in the virtual world, as has been argued in a similar context regarding Internet Service Providers, ${ }^{315}$ they can be held responsible by real

\footnotetext{
${ }^{314}$ See Lastowka \& Hunter, supra note 13 , at 5.

${ }^{315}$ Compare Douglas Gary Lichtman \& Eric A. Posner, Holding Internet Service Providers Accountable 41-42

(U. CHI. L. \& ECON. Olin Working Paper No. 217, 2004), available at
} 
world regulation. In this respect it would not matter whether the virtual worlds companies own all of the content of their virtual world. The responsibility to enforce regulation is related to their ability to control, and understandably, they hold this control. In this important way, virtual worlds companies are like Napster. ${ }^{316}$

This proposed solution might lead to two different reactions. First, virtual worlds companies might advertise the regulation frame they offer in competing for clients. Second, competition might arise between real world legislatures regarding the liability level imposed on virtual worlds companies; the more virtual worlds companies create positive annual flows for the real world jurisdiction by which they are governed, real world legislatures might become hesitant in legislating rules that harm local economic engines and therefore impose less liability on virtual worlds companies. ${ }^{317}$ While the first reaction to regulation is positive, the second reaction is problematic for two reasons. First, jurisdiction issues might be problematic in virtual worlds and therefore the proposed solution might be weakened in this context. Second, since the controlling jurisdiction will want to encourage the use of virtual worlds under its governance, there are two contradicting possibilities: creation of heightened liability that will encourage virtual worlds ideal for minor users or reduced liability that will increase customer attraction to virtual worlds.

This proposed solution has several advantages. First, it creates competition between virtual worlds with regard to regulation and creates a variety of regulation solutions for the

\footnotetext{
http://papers.ssrn.com/sol3/papers.cfm?abstract id=573502 with Michael D. Birnhack \& Niva Elkin-Koren, The Invisible Handshake: The Reemergence of the State in the Digital Environment, 8 VA. J.L. \& TECH. 6 (2003).

${ }^{316}$ Napster operated a centralized database, indexing all files on the network. See A\&M Records, Inc. v. Napster, Inc., 239 F.3d 1004 (9th Cir. 2001). Napster's liability for contributory and vicarious copyright infringement was affirmed by the Ninth Circuit in 2001. See id. The court held that Napster's actual knowledge of the infringing activities, and its material contribution to infringement by its ongoing provision of the site provided a basis for contributory liability. See id. at 1021-22. See also Robin D. Gross, 9th Circuit Napster Ruling Requires P2P Developers Ensure No One Misuses Their Systems: Supreme Court's “Betamax” Defense to Secondary Liability Narrowed (Feb. 26, 2001), http://www.eff.org/IP/P2P/Napster/20010226_rgross_nap_essay.html (last visited October 27, 2010).

${ }^{317}$ See, e.g., Catherine Gage O'Grady, Targeting State Protectionism Instead of Interstate Discrimination Under the Dormant Commerce Clause, 34 SAN DIEGo L. REV. 571, 575 (1997) (arguing that "the primary concern in evaluating local regulations ought to be the long-recognized prohibition against resident economic protectionism.”).
} 
user to choose from. Second, similar to the self-regulation model, ${ }^{318}$ virtual worlds companies, possessing the control and the knowledge, will be those determining the regulation while the legislature will impose liability on them if they fail to properly regulate their virtual worlds.

Nonetheless, this solution also has several disadvantages. First, it is not certain that the users will pay attention to the regulation methods suggested to them by the virtual world, or that they will choose the suitable method of regulation for themselves. Second, it is reasonable to assume that the market forces will create a situation in which the legislature might prefer imposing less liability on virtual worlds companies in order to allow them to draw customers more easily and enrich the jurisdiction treasury. Finally, we are dealing with ex-post regulation that might discourage real world legislatures from efficiently regulating virtual worlds. $^{319}$

\section{(4) "No Sale" Servers}

Another proposed solution, aimed at addressing the issue of minors dealing in virtual property, labor, gambling and money (real and virtual), suggests separating the servers operating the virtual world into two categories: "for sale" servers, meaning the regular servers operating today, and "no sale" servers that will allow use of the virtual world but will not allow real money transactions involving virtual items, currency or Avatars. ${ }^{320}$ Minors will be limited to use only "no sale" servers, regulated by the surveillance mechanisms of virtual worlds such as registration details, credit card details, fax verification, and other means. Virtual worlds companies will be responsible for operating these two server types as well as ensuring that minors will use only the "no sale" servers. If these "no sale" servers are created,

\footnotetext{
${ }^{318}$ Sugerman, supra note 309 , at 1045.

${ }^{319}$ Viktor Mayer-Schönberger \& John Crowley, Napster's Second Life?: The Regulatory Challenges of Virtual Worlds, 100 Nw. U. L. REV. 1775 (2009).

${ }^{320}$ See Mark Methenitis, Internet Gambling Regulation Present and Future: Technology Outpaces Legislation as the MMORPG Problem Emerges, (2005), available at $\mathrm{http}: / / \mathrm{ssrn} . \mathrm{com} / \mathrm{abstract=987056}$.
} 
minors can be restricted to only using them, while adults can choose between "sale" and "no sale" servers, similar to the choice between PVP and non-PVP servers. ${ }^{321}$

\section{(5) Virtual Worlds Council}

Another proposed solution is establishing a virtual worlds council whose responsibility it will be to regulate virtual worlds and help reduce the dangers of these worlds to minor users. This council can set regulation norms and homogenous Terms Of Service for all virtual worlds, and the mere existence of the council and the guidelines it will issue, will allow courts to rule consistently on virtual worlds issues. This council can also collectively create a virtual world regulation model and create standardized bodies for virtual worlds to guide real world legislatures.

Organizing this council would be a difficult task. Nonetheless, credit card companies launched a similar effort in 2006 called the PCI Security Standards Council. ${ }^{322}$ This council's purpose was to develop uniform information security standards that were implemented in the information security program of each company. ${ }^{323}$ This self-regulation is similar to the regulation in the video games field and might help to solve the problems set forth above.

\section{B. The Tort Aspect}

In light of the aforementioned research, it can be concluded that the intensity of the use is the main factor connected to the dangers and damages that might be caused to minors by use of virtual worlds. Additionally, it is clear that emphasis should be placed on the dangers that might stem from virtual worlds use, and that minors and their parents should be

\footnotetext{
${ }^{321}$ Servers can have different sets of roles. The most common outline is player-versus-player servers, compared with player-versus-non-player servers. The difference is that the first kind of servers allows players to attack one another while the second kind forbids this behavior. Some users prefer one kind of server to the other while others use Avatars in both kinds of servers.

${ }^{322}$ Gilbert, supra note 118 , at 245.

${ }^{323}$ Id.
} 
warned of these dangers. Therefore, efforts at regulation will be the most efficient where they lower the intensity of use and maximizing awareness of the Phenomenon. One possible suggestion is to add to the Consumer Protection Act sections emphasizing the dangers of Internet use, in general, and especially emphasizing the dangers of programs targeted at youth. The Act could also regulate minors use to prevent danger, where possible, and impose liability on virtual worlds companies that do not adhere to these new sections of the Act. The orders will be based on four main factors: awareness, prevention, help and liability, and will be implemented by an integration of the regulation models reviewed above.

\section{(1) Awareness}

Virtual worlds companies will publish on the virtual world website and in the media, a warning about the dangers of virtual worlds' use by minors, including research supporting this claim. Additionally, virtual worlds companies will be obligated to issue warnings, similar to the warnings on cigarette packages, stating that virtual worlds use might be addictive, may have serious negative impacts on real world behavior, and might cause creative imagination decline.

\section{(2) Prevention}

Virtual worlds companies will use technological means to locate minor users. These means can include identification measures that will be in operation during the virtual world's user registration, such as credit cards details, fax verification request, cell phone details, etc., as well as identification means that will be used after the user begins using the virtual world, such as addressing the user, tracing his using habits and identifying user characters typical to minors. A trace will occur for all users identified as minors, in order to monitor continuous using time. If the use exceeds the set standard, it will be reported to the minor's parents and, if 
the use is not reduced, the minor will be blocked from using the virtual world. A time counter will appear permanently on the virtual world user screen that will show the user exactly how long he has been in the virtual world. Additionally, after period of time that exceeds the defined permitted use length, the user will lose "points" (virtual property or other virtual valuables) in the virtual world, a sanction meant to incentivize the user to take a break. If the user does not stop after the sanction, a mechanism forcing the user to stop the use will be activated.

\section{(3) Help}

Virtual worlds companies will establish help centers that minors and parents can approach about harms and/or feelings of distress caused by the minor's use of virtual worlds. In addition, virtual worlds companies will be forced to place distress buttons inside the virtual environment. On one hand, it is desirable to have the option for anonymous distress button use; otherwise, users will be afraid to use distress buttons for fear of removal from the virtual world use. On the other hand, a call for help should be reported, at the very least, to the minor's parents. This point needs development beyond the scope of this article.

\section{(4) Liability}

Virtual worlds companies that do not fulfill the stated requirements will bear liability; civil in the case of economic damages, and criminal in the case of bodily damage, as long as it is proven that the damage to the minor user was caused by virtual world use.

\section{SUMMARY}

Combining the four factors on which the rules will be based with legislation addressing the dangers posed to minors in virtual worlds may not only reduce the current 
harm, but may also constitute an appropriate first step toward the improvement of virtual worlds in the future. In light of the power of virtual worlds and the vulnerability of minors, only an appropriate and preemptive legislative response can minimize the already evident damages and prevent greater damages in the future. While at this time legislation might seem "harsh" and "intervening," it is important to remember that we are dealing with a futurefacing measure, and it is, therefore, best to implement it as soon as possible. While regulating virtual worlds in the economic-property context is important, it is important to remember that the dangers posed to minors in virtual worlds do not allow for space for hesitant discussion. It is overwhelmingly clear that young souls are at risk.

It is possible that the suggested regulation will not prevent dangers to minors in virtual worlds, and it is also possible that there will be tragedies, which unfortunately will occur even after the implementation of the proposed solutions. However, failure to take action now and implement the proposed solutions could quickly bring us to a point where the damages suffered by minors in virtual worlds are severe, and yet the virtual worlds have become too powerful to regulate.

\section{SUMmary ANd CONCLUSIONS}

This article sought to answer two questions: 1) Is there a need to regulate minors use of virtual worlds in light of the damages that might be caused by Internet addiction and blurring of borders? and 2) Assuming that the answer to the first question is yes, what is the desired regulation? The methodology used to examine these questions was based on a comparative-critical review of the literature relevant to this interdisciplinary issue: (1) Technology - virtual worlds, current situation and future potential; (2) Psychology and Philosophy - the damages that can be caused to the minor user; (3) Law and Society regulation and current law in California and China; (4) Law and regulation - the desired law. 
Research on these issues reveals that the damage that might be caused to minors from use of virtual worlds is significant. Moreover, in comparison to damages related to other information technologies, the damages that might be caused due to the use of virtual worlds are unfamiliar in their nature, strength, and scope. Indeed, in early research conducted on other information technologies, similar damages were found: video games create a blurring of borders and Internet use can create Internet addiction. This article assumes, however, that the damages caused by virtual worlds use will be much more severe and will require additional care.

Additionally, it is reasonable to assume that we will be unable to estimate the full scale of damages caused to minors today until those minors become adults, carrying with them the negative cargo of virtual use damage. This forecast is especially relevant to physiological changes that might be caused to the brain, from the use of virtual worlds. The review of the current law also supports the assumption that we are not prepared to deal with the damages that might be caused by virtual worlds use. In California, freedom of speech and Internet Service Provider immunity create barriers to imposing liability on virtual worlds companies for the damages that might be caused to minors. Additionally, these immunity mechanisms are typical in most Western jurisdictions. Moreover, the tort system, which is meant to provide recovery for damages, is not prepared to deal with mental damages from virtual worlds use, especially while it remains true that virtual worlds are not defined as dangerous by nature. Parental responsibility is also not clear in this regard, especially since parents' understanding in this field is usually inferior to that of their children. Moreover, the current defenses that protect minor users in the realm of consumer-protection and products liability do not provide an appropriate remedy in light of the non-obliging rating system, which gives some virtual worlds (MMORPG's) a seal of approval for their activity, and in light of the fact that social virtual worlds are usually not rated. 
Therefore, in light of the potential damages reviewed above, a conclusion can be drawn that minors are at risk due to the use of virtual worlds. Such a risk cannot be properly regulated with means that are not legal. This conclusion is supported by reference to current laws that do not respond to the existing risk potential. Therefore, the solution outlined in this article should be implemented in order to regulate minors' use of virtual worlds - the sooner the better.

Nonetheless, the research on virtual worlds, and especially the aspects discussed in this article, is very limited. There is a need to further review the assumptions made in this article. Several observations require further analysis and further research exceeding the scope of this article. Examples of potential future research include: the distinction between MMORPG's and social virtual worlds; the distinction between the term "use" and "play;" the distinction between "scripted" virtual worlds in which the script was written in advance and "non-scripted" ones, in which the content is based on the users; and further review of the current law in additional jurisdictions. Each of these areas has the potential to be instructive, and to provide greater insight into this relatively new Phenomenon. 